\title{
ECONOMICS
}

\section{MIGRANT NETWORKS AND TRADE: \\ THE VIETNAMESE BOAT PEOPLE AS A NATURAL EXPERIMENT}

by

Christopher Parsons

Business School

University of Western Australia

and

Pierre-Louis Vézina

King's College London 


\title{
Migrant Networks and Trade: The Vietnamese Boat People as a Natural Experiment
}

\author{
Christopher Parsons * $\quad$ Pierre-Louis Vézina $^{\dagger}$
}

January 13, 2016

DISCUSSION PAPER 16.04

\begin{abstract}
We provide cogent evidence for the causal pro-trade effect of migrants and in doing so establish an important link between migrant networks and long-run economic development. To this end, we exploit a unique event in human history, i.e. the exodus of the Vietnamese Boat People to the US. This episode represents an ideal natural experiment as the large immigration shock, the first wave of which comprised refugees exogenously allocated across the US, occurred over a twenty-year period, during which time the US imposed a complete trade embargo on Vietnam. Following the lifting of trade restrictions in 1994, US exports to Vietnam grew most in US States with larger Vietnamese populations, themselves the result of larger refugee inflows 20 years earlier.
\end{abstract}

JEL classification: F14, F22

Keywords: Migrant Networks, US Exports, Natural Experiment.

*Economics (UWA Business School), The University of Western Australia, 35 Stirling Highway, Crawley, WA 6009, Australia. Email: christopher.parsons@uwa.edu.au.

${ }^{\dagger}$ Department of Political Economy and King's International Development Institute, King's College London, London, WC2R 2LS, UK. mail: pierre-louis.vezina@kcl.ac.uk.

We would like to thank Mary May at the US Census Bureau for dealing with our data purchases. We are also grateful to Michel Beine, Andy Bernard, Lorenzo Caliendo, Christian Dustmann, Giovanni Facchini, Gabriel Felbermayr, Tommaso Frattini, Beata Javorcik, Mary Lovely, Friederike Niepmann, Lindsay Oldenski, Thi Thu Tra Pham, Ferdinand Rauch, Richard Upward, Chris Woodruff and Alan Winters as well as participants at the 2013 Midwest Trade Meeting at the University of Michigan, the 2013 Junior Economist Workshop on Migration Research in Munich, the 2014 EITI Conference in Phuket, the 2014 Royal Economic Society Conference in Manchester, the 2014 APSA conference in Washington DC, the 2014 ETSG conference in Munich and the 12th IZA Annual Migration Meeting and 5th Migration Topic Week, Dakar 2015, and at seminars at the Universities of Bournemouth, Nottingham, Oxford, Southampton, Sussex, Birmingham, Kent, at Copenhagen Business School, Moscow's New Economic School and Royal Holloway, for timely and useful comments. 


\section{Introduction}

David Tran, once a Major in the South Vietnamese army, fled from Vietnam in 1979 following the Sino-Vietnamese war. After time in a United Nations refugee camp, he arrived in the United States in January 1980 along with thousands of refugees, collectively known as the Vietnamese Boat People. After settling in Los Angeles, he established Huy Fong Foods, naming his company after the Taiwanese freighter on which he left Vietnam. Chief among Huy Fong Foods' products is Sriracha sauce, a global brand which totalled sales of $\$ 60$ million in 2012. Strikingly, $80 \%$ of these sales were exports to Asia. Hundreds of thousands of entrepreneurial Vietnamese settled in the US from 1975 onwards that subsequently fostered US exports to Vietnam, of which Tran is just one example.

In this paper we use the exodus of the Vietnamese Boat People as a natural experiment to provide causal evidence of a long-run developmental impact of immigration, i.e. migrant networks promoting trade. Immigrants potentially foster international trade by reducing trade costs. Such frictions are quantitatively large, especially for poor countries (Anderson and van Wincoop, 2004), and are so substantial that they have been advocated as a plausible explanation for the Six Major Puzzles in International Economics (Obstfeld and Rogoff, 2001). Recent theoretical and empirical research has singled out information costs in particular as inhibiting trade flows (Chaney, 2014; Allen, 2014; Steinwender, 2013). Immigrants may lower such frictions through their knowledge of their home country's language, regulations, market opportunities and (informal) institutions. So too are immigrants argued to decrease the costs of negotiating and enforcing contracts by drawing upon their trusted networks, thereby deterring opportunistic behavior in weak institutional environments (Greif, 1993; Gould, 1994; Rauch, 2001; Rauch and Trindade, 2002; Dunlevy, 2006). This is important, since weak institutions have been shown to significantly and adversely affect trade volumes (Anderson and Marcouiller, 2002; Berkowitz et al., 2006). Migrants are thus typically expected to facilitate bilateral 
trade mostly with developing countries, where firms typically need to navigate myriad bureaucratic and legal hurdles, Vietnam being a case in point.

While a large literature examines the pro-trade effect of migration, causality from migration to trade has yet to be conclusively established (Felbermayr et al., 2015). Studies almost ubiquitously uncover a positive correlation between migration and trade (Genc et al., 2012), to the extent that these results are often interpreted as evidence of a positive diaspora externality. Doubts persist however, as to whether trading partners' cultural affinity or else bilateral economic policies might be driving the observed positive correlations (Lucas, 2005; Hanson, 2010). These doubts are valid, not least since the estimated impacts of immigration on trade are quantitatively large, therefore representing an important economic channel through which migration might lead to substantial gains from trade.

To address these endogeneity concerns, we use the exodus of the Vietnamese Boat People to the US as a natural experiment to establish a clear causal effect from Vietnamese immigration to US trade with Vietnam. The exodus started in April 1975, following the Fall of Saigon to the Communist North Vietnamese, when the US military evacuated around 130,000 refugees from South Vietnam. A major part of this evacuation was Operation Frequent Wind, the largest boat and air lift in refugee history. This first wave of refugees was, as we will detail in the next section, exogenously dispersed throughout the US. It constituted the first of many waves, as subsequently hundreds of thousands of Vietnamese refugees fled Vietnam to escape protracted persecution in 're-education camps' and agricultural collectives. Between 1975 and 1994 around 1.4 million Vietnamese refugees were resettled in the US. Concurrently, the US imposed a trade embargo on all Vietnam, under the auspices of the 1917 Trading with the Enemy Act and the 1969 Export Administration Act. Our natural experiment thus combines a large immigration shock of Vietnamese refugees to the US - the first wave of which was exogenously dispersed 
across US States - in tandem with a lasting trade embargo. These events constitute an ideal natural setting to test the causal link from Vietnamese immigration to US exports to Vietnam following the lifting of the trade embargo in 1994.

Figures 1 and 2 pictorially demonstrate our identification strategy. Figure 1 plots the immigration waves of Vietnamese to the US (dotted line), with three spikes corresponding to the Fall of Saigon, the Sino-Vietnamese War and later the introduction of US policies designed to welcome additional waves of Vietnamese refugees. These massive immigration shocks preceded the opening up of trade with Vietnam in 1994, which led to a rise in US exports to Vietnam (bold line) that was particularly pronounced in the late 2000s. Figure 2 shows that the exogenous allocation of the first wave of 130,000 refugees in 1975 is strongly correlated with the location of Vietnamese migrants in the US in 1995, the first year after the lifting of the trade embargo. We thus use the chronology of events and the exogenous allocation of the first wave of refugees (as an instrumental variable), to establish a causal link from migrant networks in 1995 to trade creation between 1995 and 2010.

Our results show that US exports going to Vietnam over the period 1995-2010, i.e. following the lifting of the trade embargo in 1994, grew most in those US States with larger Vietnamese populations, themselves the result of larger refugee inflows two decades beforehand. Our baseline, 1995-cross-section results suggest that a 10\% increase in the Vietnamese network raises exports to Vietnam by between $4.5 \%$ and $14 \%$. Our results are robust when we additionally consider: the extensive margin, expressing exports in shares as opposed to levels, outliers and different types of goods traded. Furthermore we undertake a number of placebo exercises that further validate our results. In panel regressions, in which are further able to impost state fixed effects, we uniquely document how the overseas Vietnamese, known as the Viet Kieu, took advantage of a bilateral trade agreement signed between the US and Vietnam in 2001, in addition to Vietnam's 
policies aimed at leveraging overseas Vietnamese contributions to national development, an important example of a successful Diaspora-engagement program. To further qualify the magnitude of our results, we examine counterfactual scenarios that simulate how large the export flows to Vietnam would have been had migrant inflows into the corresponding US States have been $95 \%$ lower. These simulations show that on average, across the ten States with the highest Vietnamese populations, exports to Vietnam would have been $50 \%$ lower.

Our paper is the first to provide evidence from a natural experiment of the causal relationship between migrant networks and international trade, thereby addressing an issue that has lingered for over two decades of empirical research. Taking a broader perspective, our results provide evidence of the positive long-term economic benefits of immigration, namely export creation, thus emphasizing a strong channel through which migration may foster development. Building upon Gould's seminal insight (Gould, 1994), our results lend further support to the idea that immigrants are fundamentally differentiated from native populations in terms of their ties with their home nations. These ties, maintained by a common language and regular flows of information, ${ }^{1}$ bring nations closer together and represent an important channel through which immigrants nurture long-run development, in our specific case through fostering trade.

Gould (1994) originally hypothesised two channels through which migrants may foster trade flows. He argued that immigrants may positively affect trade by reducing transaction costs by providing foreign market information, the so-called information channel and by maintaining preferences for imports from their origin countries, what he termed the preference channel. By concentrating upon the effect of (Vietnamese)

\footnotetext{
${ }^{1}$ Despite the circumstances under which the first waves of Vietnamese left the country, Vietnamese refugees kept contact with families and friends in Vietnam. As Zhou (1997) writes, "Letters frequently moved between the receiving countries and Vietnam". Moreover the first companies that established long-distance telephone and flight services to Vietnam after 1994, drastically reducing information barriers between the two countries, were founded by Vietnamese migrants.
} 
immigration on (United States') exports, we isolate the necessarily welfare-enhancing information channel. Nonetheless the immigration shock might have also led to 'nostalgia' imports from Vietnam in addition to the opening of many restaurants and other businesses that rely on Vietnamese-specific skills and imports. These potentially translate into gains from variety for US consumers (Chen and Jacks, 2012) and export-led poverty reduction in Vietnam (McCaig, 2011).

The following Section provides an historical account of the events that followed the Fall of Saigon and in doing so elucidates our natural experiment. Section 3 presents our data and empirical model. Our results are then presented in Section 4, which in turn allow us to simulate counterfactual scenarios so as to quantify how much trade creation would have occurred in the absence of the Vietnamese Boat People. Finally Section 5 concludes.

\section{The Natural Experiment}

In this section we describe the chronology of events surrounding the exodus of the Vietnamese Boat People from Vietnam to the US. The Fall of Saigon to the Soviet-backed Communist Vietnamese North in April 1975 proved the catalyst for the first wave of refugees from Vietnam, as the communist North pursued their wartime enemies, forcing over one million people into 're-education camps' and 'New Economic Zones' i.e. agricultural collectives. Following the first wave, hundreds of thousands of Vietnamese fled overland and by sea relying on watercraft, often fishing boats, giving rise to their name "The Boat People'. Those Vietnamese that were able to leave, fled overland to Cambodia, Laos, and Thailand - or else headed for the open seas, to international waters and busy shipping lanes. ${ }^{2}$ The fortunate were rescued by ship crews and taken to refugee camps

\footnotetext{
${ }^{2}$ According to the UNHCR, over 250,000 refugees died on the open sea "as a result of storms, illness, and starvation, as well as kidnappings and killings by pirates" (US House, 2010).
} 
in Hong Kong, Malaysia, Thailand, Indonesia and the Philippines, the so-called 'first asylum countries', where they typically faced squalid conditions.

In response to the unfolding crisis, The President's Special Interagency Task Force (IATF) for Indochina refugees was established on 18 April 1975 to co-ordinate all relevant agencies involved. The refugee program consisted of three separate phases, i) the evacuation of 140,767 refugees, ii) the refugees' temporary care while they waited to be permanently settled and iii) the resettlement of the refugees either in the US $(132,421)$, in third countries, largely Canada and France $(6,632)$ or else to ensure their successful repatriation to Vietnam $(1,546)$. The vast majority of refugees that ended up residing in the US were processed through one of four camps on US soil, deliberately scattered in dispersed geographical locations, namely Fort Chaffee (Arkansas, 50,135), Camp Pendleton (California, 48,418), Fort Indiantown Gap (Pennsylvania, 21,651) and Elgin Air force Base (Florida, 8,665). There 19 voluntary agencies (VOLAGs), predominantly religious organizations, helped the Vietnamese to settle in the US by matching them with sponsors, for example with US citizens that offered food, clothing and shelter until the refugees were financially independent. ${ }^{3}$

The program of refugee resettlement began under emergency conditions and was carried out hurriedly. Due to the unprecedented scale and urgency of the refugee program, citizens, churches, and employers across the US were urged to sponsor refugees (Sonneborn and Johnston, 2007). Over a 32-week period, from 11 May to 20 December 1975, 4,000 Vietnamese refugees on average, were released from the refugee program each week (Figure 3). By 20 December 1975, 130,000 refugees had been resettled in the US. The 1975 resettlement process culminated in an exogenous distribution of Vietnamese across the US, uncorrelated with immigrants' preferences and economic opportunities related

\footnotetext{
${ }^{3}$ Since World War II, refugees in the US have been resettled by voluntary agencies, for example those from Hungary (1956) and Cuba (1960). The Indochinese were no exception as "expertise and experience were needed, since the US had never before experienced the arrival of so many refugees in so short a time" (GAO, 1977).
} 
to trade with Vietnam. There are two main reasons why we argue this distribution is quasi-random.

The first is that the refugees were purposefully dispersed throughout the US as policymakers, drawing on the lesson from the agglomeration of Cubans in Miami, were keen to avoid the development of a similar Vietnamese refugee agglomeration. ${ }^{4}$ Haines (1996) writes that "During House debate on the Indochina Migration and Refugee Act 1975 several speakers...referred repeatedly to the need to distribute refugees evenly about the country, to minimize impact upon specific labor markets and communities... This became the explicit policy of refugee resettlement for the Indochinese". This sentiment is corroborated by a statement made by Kenneth Fasick, Director of the International Division of the US General Accounting Office, before The Subcommittee on Immigration, Refugees, and International Law, Committee on The Judiciary of the US House of Representatives on 16 May 1979: "To avoid the kind of geographic concentration experienced with the Cuban refugees, an effort was made at the time of the initial resettlement wave in 1975-76, to distribute the refugee population throughout the US." In the words of the Sociologist Ruben G.Rumbaut (1995), the "goal of resettlement through reception centers was to disperse refugees to 'avoid another Miami'...Consequently the initial resettlement efforts sought a wide geographic dispersal of Vietnamese families." According to Zhou and Bankston (1998), “...the US Government and the voluntary agencies working mainly under government contracts oversaw their resettlement and in most cases decided their destinations... The effort to minimize impact [on US Society] led initially to a policy of scattering Southeast Asians around the country...the early attempts at dispersion gave rise to Vietnamese communities in such places as New Orleans, Oklahoma City, Biloxi, Galveston and Kansas City, that had previously received few immigrants from Asia." It was no coincidence that the camp that received the greatest number of refugees was also

\footnotetext{
${ }^{4}$ Card (1990) analyzes the labor market effect of the Mariel Boatlift of 1980, when around 125,000 Cubans settled in Miami and finds little evidence of immigration affecting unemployment or wages.
} 
located in a State that had historically been the least attractive to migrants, Arkansas (Robinson, 1998). Moreover, as Vo (2006) argues, the goal of the dispersion was also to minimize the cost on host societies: ...the US resettlement program planned to disperse them equally throughout all the States. The goal was not to assimilate the refugees but to limit the cost of social health and educational services incurred by counties with large numbers of refugees." The dispersion policy led to a higher number of refugees in the most populous States, the data for which i.e. the number of refugees per State on 31 December 1975 are provided in Table 1).

The second reason why the resettlement process was quasi-random is because the process of refugee allocation was anarchic and differences in agencies' pro-activeness resulted in a mal-distribution of caseloads. Refugees would need to register, some by choice and others by assignment, with a voluntary agency committed to finding them (and their families) a sponsor. ${ }^{5}$ In theory, the matching process "consisted of reviewing the refugees' occupational background against a Department of Labor's listing of labor markets needing additional workers, comparing refugees' preferences for place of resettlement against the agency's opportunities, and assigning the refugees to a sponsor in the chosen locality" (Baker et al., 1984). Thompson (2010) provides examples of some adverts for workers published in the camp newspaper from Indiantown Gap: "Workers for greenhouses in Maryland and North Carolina. Free housing, food, assistance, and wages." or "Two fisherman needed for job in Florida. Position pays \$2.10 per hour with sponsorship. Housing to be provided in new house trailer plus farm animals and garden. Should be able to sex-sort and count fish." Importantly however, despite this hypothesized process, the reality on the ground was very different, such that ultimately nearly three-fourths of the sponsors chosen were either families or individuals as opposed to firms offering jobs

\footnotetext{
${ }^{5}$ In the first months of the program refugees could turn down offers of sponsorship. As noted by Thompson (2010), of the 1,213 offers recorded at Indiantown Gap by the Sponsorship Coordination Center, 759 were eventually accepted. From October 1975 onwards, the US government made it almost impossible for a refugee to refuse an offer of sponsorship.
} 
(Marsh, 1980).

Thompson (2010) writes that Washington put tremendous pressure on the agencies, emphasizing the need for expeditious processing. He quotes the Department of Health, Education and Welfare Director, who noted that "Everyone worked 12-hour shifts, 7 days a week, and it was not uncommon to work 15 or 16 hours at a time." Never before had the responsible agencies been required to resettle such unprecedented numbers in such a short space of time. The chaos that ensued in the camps led to confusion among the refugees with regards to which agency to sign-up with. The signing-up in large part was a function of how pro-active agency employees were. In Fort Chaffee for example, two agencies registered about $75 \%$ of the refugees and other agencies complained of a mal-distribution of caseloads (Thompson, 2010). Robinson (1998) cites a voluntary agency worker at the time as saying "Nobody quite knew who was doing what. Most of what we were doing was matchmaking... We felt we were competing with one another to get people out of there".

The organizations responsible for dispersing the Vietnamese throughout the country had sponsors in specific geographical locations across the United States. The matching with relocation agencies therefore in part determined the destination of many of the refugees. Since religious organizations resettled the vast majority of the refugees (in particular the Catholic Conference $(59,901)$, the Church World Service $(18,126)$ and the Lutheran Immigration and Refugee Service $(17,051))$, many of the refugees were assigned a State on the basis of the location of parishes or dioceses. In the words of Thompson (2010), "The Lutheran church was strongest in the upper Midwest and resettled many refugees in Minnesota and neighboring States - and to this day Minnesota is home to many Indochinese despite its bone-chilling winters". Moreover, "the religious VOLAGs...were less tied to specific job offers in settling refugees. A parish or church often sponsored their clients without a commitment on the part of the refugee to accept a particular job 
(Thompson, 2010). This explains why only around $25 \%$ of the sponsors chosen were firms offering jobs (Marsh, 1980).

Due to the cluster-avoiding US-government-led dispersion policy as well as the differences in pro-activeness across relocation agencies, in most cases the refugees "were powerless to decide where and when they would be resettled the resettlement agencies almost entirely decided where the refugees would settle" (Zhou and Bankston, 1998). This is further revealed by the large flows of secondary migration that took place in the following years, which occurred in the absence of government controls. In large part, this process was driven by the desire to reunite extended families separated during the resettlement process (Sonneborn and Johnston, 2007), as well as a preference for warmer climates and more generous social welfare programs (Vo, 2006). According to Baker et al. (1984), 40.6\% of those who did not receive their choice of State had moved by 1978, as well as $33.8 \%$ of those who had first resettled to the State of their choice. ${ }^{6}$ This suggests that $45 \%$ of refugees for whom we know residence, lived in a different State in 1980 than in 1975. Similarly, the same study reveals that in a poll conducted on the basis of random telephone calls in 1981, 33\% of the respondents had moved across State lines since their arrival in the US. This secondary migration strongly suggests that the initial placement was exogenous to migrants' preferences.

Most importantly, the data show that economic and political variables played no role in the allocation process. As shown in Figure 4, the number of refugees hosted across States is not correlated with state income per capita, the degree of state openness to migrants (captured by the immigrant share of State populations), remoteness from US 1978 customs ports (from where goods officially leave the US) or state unemployment. The figure also shows that the allocation of refugees was not driven by differences in

\footnotetext{
${ }^{6}$ The analysis of Baker et al. (1984), although partial, indicates that overall some $47.3 \%$ of the refugees were sent to the State of their choice. When asked at the camp interview about their preferences for a State of resettlement almost half wanted to go to California, but only a fifth were sent there. Less than a quarter wanted to go to the 43 least-favored States, yet more than half were sent to those places.
} 
attitudes towards the US involvement in Vietnam in 1972, which could have affected sponsorship offers. Our scatter plot shows that the number of refugees by State is not correlated with the share of votes for the Democrat party in 1972, when George McGovern's 1972 Presidential Campaign called for the immediate withdrawal of US troops from Vietnam and lost 49 of 50 States to Richard Nixon. Finally, while the US census of 1970 records some 1,800 Vietnamese, mostly family members of American soldiers in addition to students, residing in the US at that time (of which 29 States in 1970 hosted zero migrants), the allocation of refugees is not correlated with the State's population share of Vietnamese in 1970 nor with the level of Vietnamese in 1970 once we control for State size (GDP). This suggests that the allocation of refugees in 1975 was indeed independent of any earlier settlement.

This initial distribution of Vietnamese persisted, despite the secondary migration and led to the emergence of Vietnamese communities, as additional waves of refugees arrived in the US and drew on pre-existing Vietnamese networks. As shown in Figure 1, the exodus of the Vietnamese to the US consisted of three distinct waves; the initial wave following the Fall of Saigon, the second that occurred at the time of the December 1978 Sino-Vietnamese war - which precipitated the persecution of the ethnic-Chinese population in Vietnam - and the third that coincided with the 1988 Amerasian Home Coming Act and the 1989 Humanitarian Operation Program. ${ }^{7}$ From 1980 onwards, hundreds of thousands were accepted that had previously lived in Southeast Asian refugee

\footnotetext{
${ }^{7}$ The US Government passed several important pieces of legislation to facilitate the arrival of the Vietnamese. The 1979 Orderly Departure Program allowed Vietnamese to legally emigrate on the basis of family reunion and on humanitarian grounds and estimates suggest that by the mid-1990s over two hundred thousand Vietnamese had entered the US under the Program. In 1980, the US Congress passed the Refugee Act - the most comprehensive piece of refugee legislation in US history - into law, which revised the provision of the 1965 Hart-Celler Act that previously admitted refugees into the US in limited proportions relative to the overall number of immigrants. The Amerasian Homecoming Act was passed in the US in 1988 to bring as many Amerasians to the US as possible. The final important piece of legislation passed by the US Congress to aid the Vietnamese was the 1989 Humanitarian Operation Program. In that year, the US and Vietnamese Governments agreed for former and current detainees in 're-education camps' to be allowed to depart for the US, the ultimate consequence of which was the arrival of a further 70,000 Vietnamese.
} 
camps.

Whereas the US Government facilitated inward movements of Vietnamese Boat People to the US, their stance with regards to the movement of goods between the two nations was quite the reverse. Under the auspices of the 1917 Trading with the Enemy Act and the 1969 Export Administration Act, and following the military conquest of Saigon in 1975 by the Communist North, the US widened trade sanctions, ostensibly a complete trade embargo, from its previous focus on the North of Vietnam, which had been in place since 1964, to the entire country. On 3 February 1994, President Clinton lifted the trade embargo at a time of increased lobbying by private domestic firms who were reported by the Los Angeles Times to be 'champing at the bit' to do business in Vietnam. ${ }^{8}$ The quasi-randomly allocated first-wave of Vietnamese refugees, in tandem with the lasting trade embargo constitute an ideal natural experiment with which to establish a causal effect of Vietnamese migrant networks on US exports to Vietnam.

\section{Data and Empirical Strategy}

As detailed in the previous section, the 1975 distribution of Vietnamese refugees was quasi-random and constitutes an ideal instrumental variable with which to establish a causal effect of Vietnamese migrant networks on US exports to Vietnam. The enduring trade embargo complements our instrument by conclusively insulating our results from concerns of reverse causality i.e. the endogenous location decision of migrants, whereby refugees could potentially have located in areas with more favorable trading opportunities.

Random allocations of refugees have been used for identification purposes in previous studies. For example: in Sweden by Edin et al. (2003) who estimate the causal effect of

\footnotetext{
${ }^{8}$ Relations between the two nations improved following a sustained effort by the Hanoi Government to assist US forensic teams locate and identify over 2,000 US service personnel that were still listed as Missing In Action at that time. A normalization of diplomatic relations ensued in 1995, with the upgrading of the liaison offices to full embassy status
} 
immigration on labor market outcomes, by Dahlberg et al. (2012) to estimate the effect of ethnic diversity on redistribution preferences and, in a slightly different approach, by Damm and Dustmann (2014) who investigate the effect of exposure to crime on criminal behavior across Danish neighborhoods. Our study is the first to use such an allocation to establish a trade-creation effect of migrants. ${ }^{9}$

We use the exogenous allocation of Vietnamese refugees in 1975 as an instrument for the stock of Vietnamese migrants across US States in 1995, the first (full) year in which the US exported to Vietnam. The 1975 refugee location data are obtained from a US General Accounting Office Report to Congress (GAO, 1977). It provides the number of refugees resettled by State as of 31 December 1975, importantly just eleven days after the last camp closure. Migration data for the year 1995 are taken from the 2000 US Census and derive from the question that asks respondents their place of residence five years hence. In other words, we only include in estimation those migrants in 1995 that remained in the US up until the year 2000. These anonymous micro data were obtained from the The Integrated Public Use Microdata Series (Ruggles et al., 2010). ${ }^{10}$ To demonstrate that the intensity of our instrument is not capturing differences in migrant characteristics, Figure 5 plots the number of refugees against the average age, female share, college-educated share and share of English-speaking Vietnamese. None of these characteristics are correlated with the numbers of refugees, giving us confidence that our instrument captures the number of refugees, as opposed to any selection process that may have inadvertently occurred in the observables.

Figure 6 shows the concentrations of Vietnamese across US States in $1995 .{ }^{11}$ The top

\footnotetext{
${ }^{9}$ Synchronous work by Cohen et al. (2012) uses the formation of World War II Japanese Internment Camps as an instrument to identify the impact of Japanese migrants on US exports to Japan. A particular advantage of the current study is the concurrent trade embargo.

${ }^{10}$ Our analysis can only be conducted at the State level since more disaggregated data for our instrument are unavailable.

${ }^{11}$ The Figure is constructed by applying the data for Vietnamese immigrants in 1995 from the US Census of 2000 available at the Metropolitan Statistical Area (MSA) to the corresponding map defined at the county level, such that all counties that constitute the same MSA will be defined as being host to
} 
ten metropolitan areas are listed below Figure 6. Although agglomeration occurred, most notably in California and Texas, the Figure shows the wide dispersion of Vietnamese across the country. It is important to emphasize that many populous cities do not feature prominently in Figure 6, for example, San Antonio, Jacksonville, Indianapolis and Columbus. Importantly, as shown in Figure 2, the distribution of Vietnamese in 1995 was in large part determined by the initial allocation of refugees in 1975 . The correlation between the two data series is 0.98 , such that our instrument is strong.

Our baseline cross-section regressions take the following form:

$$
X_{i}=\beta_{0}+\beta_{1} V_{i}+\beta_{2} C_{i}+\epsilon_{i}
$$

Here $V_{i}$ is the stock of Vietnamese migrants in 1995, $X_{i}$ are the exports of State $i$ to Vietnam in 1995 and $C_{i}$ is a set of control variables. We include income per capita - as richer states more likely export more differentiated products to Vietnam - and total state exports and state GDP to control for state openness and state size respectively. Our baseline model also includes a variable capturing manufacturing as a percentage of state GDP to account for the economic structure of US states and East and West coast dummy variables, which aim to capture the states' various transportation costs for exporting to Vietnam. The $\beta \mathrm{s}$ are parameters to be estimated and $\epsilon_{i}$ is the error term. We instrument $V_{i}$ with the stock of refugees in 1975 . We take the logarithms of continuous variables and thus, to ensure that our estimated elasticities are not biased due to heteroscedasticity (Silva and Tenreyro, 2005), we use a Poisson Pseudo Maximum Likelihood Instrumental variable (IV-PPML) estimator as first described in Windmeijer and Silva (1996).

Trade data are from the Foreign Trade Division of the US Census Bureau. Exports are disaggregated into 28 product categories, according to the 3-digit NAICS (North the same number of immigrants. 
American Industry Classification System) from 2002 to 2010 and the 2-digit SIC (Standard Industrial Classification) from 1995 to 2001 (see Table 2 for the concordance and classification into differentiated or homogenous goods). The main US exports to Vietnam over the period (in absolute terms) were transportation equipment and food and kindred products, while leather and forest products are important in relative terms (see Table 2). The data for our other control variables are taken from the US Bureau of Economic Analysis. Summary statistics are provided in Table 3 .

\section{Results}

Our first stage results are provided in Table 4. Columns (1) and (2) in Table 4, confirm the validity of our instrument in both our models, with and without the full set of controls. In other words, the distribution of Vietnamese refugees in 1975 is strongly correlated with the corresponding distribution in 1995. ${ }^{12}$ Our baseline second-stage results are shown in Table 5. Both reduced-form and IV estimations confirm the causal effect of Vietnamese immigrants on US exports to Vietnam along the intensive margin. A $10 \%$ rise in Vietnamese immigration to a specific US state is estimated to causally increase that states' exports to Vietnam by between $4.5 \%$ and $13.8 \%$. Our estimated $\beta$ s of interest are therefore significantly higher than most comparable estimates in the existing literature, which almost certainly reflects our context in which Vietnamese migrants could have had a larger effect on US state exports since no trade previously existed between the two nations and because information constraints between the two countries, those mitigated by Vietnamese immigrants, will likely have been very high. ${ }^{13}$

Similarly, Table 6 shows that our results are consistent when instead we analyse the

\footnotetext{
${ }^{12}$ Since these are PPML regression we do not include the usual Cragg-Donald F statistics.

${ }^{13}$ Given that the literature has shown that migrant networks influence FDI as well as trade (Aubry et al., 2014; Javorcik et al., 2011), it is worth noting that one channel through which the Vietnamese might promote exports to Vietnam is via complementary FDI flows.
} 
impact of Vietnamese migration on US state exports along the extensive margin. ${ }^{14}$ Our results indicate that doubling of Vietnamese migration increases US state exports to Vietnam by around $18 \%$, which is not inconsiderable when the breadth of our product categories is taken into account.

To confirm the validity of our results we perform a number of robustness exercises, which are presented in Table 7. Regression results in columns (1) and (2) adopt an alternative dependent variable, either exports as a share of total (state) exports or else exports as a share of state GDP, as an alternative way of capturing state size effects, while further insulating our results from endogeneity concerns. Columns (3) and (4) demonstrate that our results are robust to excluding potential outliers, either West Coast states or else California specifically. The results in columns (5) and (6) rather replace our key independent variable, the stock of Vietnamese immigrants by US state with the stock of Chinese immigrants and the stock of all Asian immigrants respectively, so as to ensure that it is specifically Vietnamese migrants that are driving the observed relationship. In the case of Chinese migrants, our results indicate that greater numbers of Chinese are associated with lower US state exports to Vietnam, while our results for all Asian migrants are insignificant. ${ }^{15}$ Finally, to check whether our results also provide evidence of the network/search view of trade (Rauch, 1996, 2001), we follow Rauch and Trindade (2002) and run our baseline regression dividing exports into differentiated goods and homogenous goods, which we define as both reference-price goods and organized-market goods (see Table 2 for the matching of NAICS code to Rauch categories). According to

\footnotetext{
${ }^{14}$ Note, given the constraints posed by the available data, our measure of the extensive margin, namely the number of industries (NAICS) with positive exports to Vietnam in 1995, is somewhat crude such that it is difficult to draw causal inferences with regards to the associated trade costs along the intensive and extensive margins.

${ }^{15}$ It might be the case that authorities allocated Vietnamese refugees to states with low Asian populations so as to avoid concentration. This would imply that information frictions with Asia were abnormally high in those states, which could lead to trade expanding disproportionately due to a mean reversion. In fact the initial allocation of Vietnamese migrants was positively correlated with existing Asian communities, although we find the overall number of Asians across states did not have any influence on US state exports.
} 
the network/search view, prices of differentiated goods fail to transmit full information in terms of their quality and characteristics to international buyers and sellers. Ethnic networks are therefore perfectly placed to be able to exploit international informational asymmetries and foster trade, particularly for differentiated products. In line with theory and the existing empirical literature, we only find a robust pro-trade effect for differentiated products.

To further corroborate our results, we run placebo regressions to ensure that our results capturing network effects are specific to Vietnamese exports. We re-estimate our baseline model substituting exports to Vietnam with exports to ten other countries in South-East and East Asia, in ten separate specifications. Our results, shown in Table 8, demonstrate that Vietnamese migrants have no effect on trade with any of the other ten countries, thereby providing additional evidence of the causal link between Vietnamese immigration to US states and US state trade with Vietnam.

Despite the initial allocation of Vietnamese Boat People in the United States being uncorrelated with the prevailing economic conditions of US states (Figure 4) and with migrant characteristics (Figure 5), the possibility that some unobserved variable being correlated with our instrumental variable still exists. To alleviate such concerns, we estimate panel regressions of the following form:

$$
X_{i t}=\gamma_{i}+\alpha_{t}+\beta_{0} V_{i} \times \alpha_{t}+\beta_{1} C_{i t}+\epsilon_{i t}
$$

Where $V_{i}$ remains the stock of Vietnamese migrants in 1995, $X_{i t}$ are the exports of State $i$ to Vietnam in year $t$ from 1995 to $2010, \alpha_{t}$ are year dummies and $\gamma_{i}$ state fixed effects. $C_{i t}$ remains our set of control variables equivalent to those in Equation 1. The corresponding results can be found in Table 9 and these are also presented in Figure 7, which shows the heterogeneity of the impact of Vietnamese immigration on the growth in the intensive margin of trade from 1995-2010. The left hand panel is estimated using PPML, while the 
right hand panel is estimated using IV-PPML. According to our IV estimates, immigrants initially did not exert any effect on the growth in bilateral trade, and the effect across States is not statistically different from that in 1995, the base year. In those years after 2005, in which we do find significant effects however, the increase in the elasticity of trade with respect to migration is on average $0.26 \%$. These interaction coefficients can also be interpreted as the additional yearly growth in exports due to Vietnamese migrants. For example, the coefficient on the 2008 year dummy, 4.112, suggests that exports were 61 times higher than in 1995 in a State with one Vietnamese (where $\ln ($ Vietnamese)=0). In an average State with 10,000 Vietnamese, exports were 406 times higher in 2008 than in 1995.

Our results indicate that States' exports to Vietnam caused by Vietnamese migration to those states largely appear after 2005. One seemingly plausible explanation for this is Vietnam's accession to the WTO on 11 January 2007. The WTO rules should not amplify the role of networks however. On the contrary, they should simplify rules with the aim of minimizing discrimination and informal practices. An alternative mechanism must therefore be responsible. One possibility is a delayed effect of another key trade-policy event, the signing of the US-Vietnam Bilateral Trade Agreement in 2001; while yet another is the 2008 Vietnamese Government Action Plan, which introduced new policies to leverage overseas Vietnamese contributions to national development, so as to encourage overseas Vietnamese to invest in and do business with Vietnam. The plan, once enacted, provided reduced land rents, cheap loans, lower interest rates, investment credit guarantees, corporate and personal income tax breaks and lowered tariffs on machinery imports. ${ }^{16}$ To analyze to what extent these policies increased the pro-trade effect of migrant networks, we run panel regressions that include a policy dummy equal to one after 2001 or 2008, which is interacted with our measure of migrant networks. We can therefore examine

\footnotetext{
${ }^{16}$ Pham (2011) reviews recent government policy toward the Vietnamese Diaspora and the latter's contribution to Vietnams economic growth.
} 
whether the trade creation effects of the 2001 or 2008 policy changes are higher in those States that host greater numbers of Vietnamese migrants. Specifically, we run the following regression:

$$
X_{i t}=\alpha_{i}+\beta_{1} P O L I C Y_{t}+\beta_{2} P O L I C Y_{t} \times V_{i}+\epsilon_{i t}
$$

where $\alpha_{i}$ are State fixed effects, POLICY $Y_{t}$ is a dummy variable that switches from zero to one in years after 2001 or 2008 . We instrument $P O L I C Y_{t} \times V_{i}$ with $P O L I C Y_{t} \times$ 1975 refugees. The results from these panel regression are found in Table 10. Both sets of IV results, that are located in columns (2) and (4), demonstrate that those states that hosted greater numbers of Vietnamese immigrants in 1995 benefited relatively more from the policy changes in 2001 and 2008. In terms of the 2008 Vietnamese Government Action Plan, the results of which are presented in the right panel of Figure 8, in those States with the largest Vietnamese networks, state exports roughly doubled after 2008 (we focus upon the four-year period around the policy change as it occurs late in our time period). In those States that hosted fewest Vietnamese, the growth of exports was still around $30 \%$. The effects of the BTA across States were of similar magnitude, as summarized in the middle panel of Figure 8. Finally, the left panel of Figure 8 summarizes the results of column (6) in Table 10, where we interacted a time trend, rather than a policy dummy, with the Vietnamese network. The idea is to generalise the previous results and estimate how the Vietnamese migrants affected the average yearly growth over the whole period. We find that moving from the lowest to the highest number of Vietnamese increases export growth by around 8 percentage points, from $23 \%$ to $31 \%$.

To further quantify the pro-trade effect of the Vietnamese migrants we simulate the counterfactual export paths of the top ten US States (in terms of Vietnamese migrants), should those States have hosted at least $50 \%$ fewer Vietnamese in 1995 . We construct a synthetic version of each State's share of exports to Vietnam, which is a weighted average 
of the variable for other States that were home to at least $50 \%$ fewer Vietnamese (the synthetic controls end up having 95\% fewer Vietnamese on average). The weights are generated so that the differences in export shares by industry and income per capita across States, from 1995 to 2010, are minimized. Each State is thus compared to a synthetic version of itself, similar in terms of income per capita and export structure, but with far fewer Vietnamese (see Abadie et al. (2010) for a detailed review of the technique). Figure 9 displays the cases of California, Texas, Massachusetts, Washington, Pennsylvania, Virginia, New York, and Illinois, eight among the top ten State hosts of Vietnamese migrants in 1995. The export performances of six of these States are much higher as when compared to their synthetic image, especially post 2005. On average, the synthetics suggest, had Vietnamese migrant stocks been around 95\% lower, that the export share going to Vietnam would have been about $50 \%$ smaller.

\section{Conclusion}

Using the exodus of the Vietnamese Boat People as a natural experiment, we establish a clear causal impact from migrant networks to trade. We exploit the exogenous allocation of 1975 refugees across US States as an instrument for immigrant stocks in 1995 and examine the effect of the latter on exports in the 15 years following the lifting of the trade embargo in 1994. We find a strong pro-trade effect of Vietnamese immigration on US state exports to Vietnam. Our baseline results show that a doubling of Vietnamese migration to US states leads to between a $45 \%$ and a $138 \%$ increase in State exports. These results are robust when we also consider: the extensive margin, expressing exports in shares as opposed to levels, outliers and different types of goods traded. In addition, we estimate a number of placebo regressions that further validate our results. Our paper is the first to provide evidence from a natural experiment of the causal relationship between 
migrant networks and international trade, thereby addressing an issue that has lingered for over two decades of empirical research. Taking a broader perspective, our results provide evidence of the positive long-term economic benefits of immigration, namely export creation, thus emphasizing a strong channel through which migration may foster development.

\section{References}

Abadie, A., A. Diamond, And J. Hainmueller (2010): "Synthetic Control Methods for Comparative Case Studies: Estimating the Effect of Californias Tobacco Control Program," Journal of the American Statistical Association, 105, 493-505.

Allen, T. (2014): "Information Frictions in Trade," Econometrica, 82, 2041-2083.

Anderson, J. E. And D. Marcoulller (2002): "Insecurity And The Pattern Of Trade: An Empirical Investigation," The Review of Economics and Statistics, 84, $342-352$.

Anderson, J. E. And E. van Wincoop (2004): "Trade Costs," Journal of Economic Literature, 42, 691-751.

Aubry, A., M. Kugler, And H. Rapoport (2014): "Migration, FDI and the Margins of Trade," mimeo.

Baker, R., D. North, And N. T. Foundation (1984): The 1975 Refugees: Their First Five Years in America, New TransCentury Foundation.

Berkowitz, D., J. Moenius, And K. Pistor (2006): "Trade, Law, and Product Complexity," The Review of Economics and Statistics, 88, 363-373. 
CARD, D. (1990): "The impact of the Mariel boatlift on the Miami labor market," Industrial and Labor Relations Review, 43, 245-257.

Chaney, T. (2014): "The Network Structure of International Trade," American Economic Review, 104, 3600-3634.

Chen, B. AND D. S. JACKs (2012): "Trade, variety, and immigration," Economics Letters, 117, 243-246.

Cohen, L., U. G. Gurun, And C. J. Malloy (2012): "Resident Networks and Firm Trade," Working Paper 18312, National Bureau of Economic Research.

Dahlberg, M., K. Edmark, And H. Lundqvist (2012): "Ethnic Diversity and Preferences for Redistribution," Journal of Political Economy, 120, 41 - 76.

Damm, A. P. And C. Dustmann (2014): "Does Growing Up in a High Crime Neighborhood Affect Youth Criminal Behavior?" American Economic Review, 104, $1806-32$.

Dunlevy, J. A. (2006): "The Influence of Corruption and Language on the Protrade Effect of Immigrants: Evidence from the American States," The Review of Economics and Statistics, 88, 182-186.

Edin, P.-A., P. Fredriksson, And O. Aslund (2003): "Ethnic Enclaves And The Economic Success Of Immigrants - Evidence From A Natural Experiment," The Quarterly Journal of Economics, 118, 329-357.

Felbermayr, G., V. Grossmann, and W. Kohler (2015): "Chapter 18 - Migration, International Trade, and Capital Formation: Cause or Effect?" in Handbook of the Economics of International Migration, ed. by B. R. Chiswick and P. W. Miller, North-Holland, vol. 1 of Handbook of the Economics of International Migration, 913 1025. 
GAO (1976): "Evacuation And Temporary Care Afforded Indochinese Refugees-Operation New Life," Report to the congress, US General Accounting Office.

(1977): "Domestic Resettlement of Indochinese Refugees: Struggle for Self-Reliance," Report to the congress, US General Accounting Office.

Genc, M., M. Gheasi, P. NiJkamp, And J. Poot (2012): "The impact of immigration on international trade: a meta-analysis," in Migration Impact Assessment, Edward Elgar, Chapters, chap. 9, 301-337.

Gould, D. M. (1994): "Immigrant Links to the Home Country: Empirical Implications for U.S. Bilateral Trade Flows," The Review of Economics and Statistics, 76, 302-16.

GreIF, A. (1993): "Contract Enforceability and Economic Institutions in Early Trade: the Maghribi Traders' Coalition," American Economic Review, 83, 525-48.

Haines, D. (1996): Refugees in America in the 1990s: a reference handbook, Greenwood Press.

Hanson, G. H. (2010): "Chapter 66 - International Migration and the Developing World," in Handbooks in Economics, ed. by D. Rodrik and M. Rosenzweig, Elsevier, vol. 5 of Handbook of Development Economics, 4363 - 4414.

Javorcik, B. S., A. Zden, M. Spatareanu, And C. Neagu (2011): "Migrant networks and foreign direct investment," Journal of Development Economics, 94, $231-241$.

LuCAS (2005): International Migration and Economic Development: Lessons from Low-income Countries, Edward Elgar Pub.

Marsh, R. E. (1980): "Socioeconomic Status of Indochinese Refugees in the United States: Progress and Problems," Social Security Bulletin, 11-20. 
MCCAIG, B. (2011): "Exporting out of poverty: Provincial poverty in Vietnam and U.S. market access," Journal of International Economics, 85, 102-113.

Obstfeld, M. And K. Rogoff (2001): "The Six Major Puzzles in International Macroeconomics: Is There a Common Cause?" in NBER Macroeconomics Annual 2000, Volume 15, National Bureau of Economic Research, Inc, NBER Chapters, $339-412$.

Pham, A. T. (2011): "The Returning Diaspora: Analyzing overseas Vietnamese (Viet Kieu) Contributions toward Vietnams Economic Growth," Working Papers 20, Development and Policies Research Center (DEPOCEN), Vietnam.

Rauch, J. E. (1996): “Trade and Search: Social Capital, Sogo Shosha, and Spillovers," NBER Working Papers 5618, National Bureau of Economic Research, Inc.

— (1999): "Networks versus markets in international trade," Journal of International Economics, 48, 7-35.

(2001): "Business and Social Networks in International Trade," Journal of Economic Literature, 39, 1177-1203.

Rauch, J. E. AND V. TRIndade (2002): "Ethnic Chinese Networks In International Trade," The Review of Economics and Statistics, 84, 116-130.

Robinson, C. (1998): Terms of Refuge: The Indochinese Exodus 65 the International Response, Politics in contemporary Asia, Zed Books.

Ruggles, S., J. T. Alexander, K. Genadek, R. Goeken, M. B. Schroeder, And M. SobeK (2010): "Integrated Public Use Microdata Series: Version 5.0," Machine-readable database, Minneapolis: University of Minnesota.

Rumbaut, R. G. (1995): "Vietnamese, Laotian and Cambodian Americans," in Asian Americans: Contemporary Trends and Issues, ed. by P. G. Min, Sage Publications. 
Silva, J. S. And S. Tenreyro (2005): "The Log of Gravity," CEP Discussion Papers dp0701, Centre for Economic Performance, LSE.

Sonneborn, L. And R. Johnston (2007): Vietnamese Americans, The New Immigrants, Facts On File, Incorporated.

Steinwender, C. (2013): "Information Frictions and the Law of One Price: When the States and the Kingdom became United," CEPREMAP Working Papers (Docweb) 1314, CEPREMAP.

Thompson, L. (2010): Refugee Workers in the Indochina Exodus, 1975-1982, McFarland, Incorporated, Publishers.

US House, . (2010): "Recognizing and appreciating the historical significance and the heroic struggle and sacrifice of the Vietnamese people..." 111th congress, 2nd session, house representatives 1331, Washington.

Vo, N. (2006): The Vietnamese Boat People, 1954 and 1975-1992, Asian and Asian American Studies, McFarland.

WindmeiJer, F. AND J. S. Silva (1996): "Endogeneity in count data models; an application to demand for health care," IFS Working Papers W96/15, Institute for Fiscal Studies.

Zhou, M. (1997): "Straddling Different Worlds: The Acculturation of Vietnamese Refugee Children in San Diego," Ethnicities: Coming of Age in Immigrant America, $187-227$

Zhou, M. And C. L. Bankston (1998): Growing Up American: How Vietnamese Children Adapt to Life in the United States, Russell Sage Foundation Press. 
Figure 1: Vietnamese inflows to the US and US Exports to Vietnam

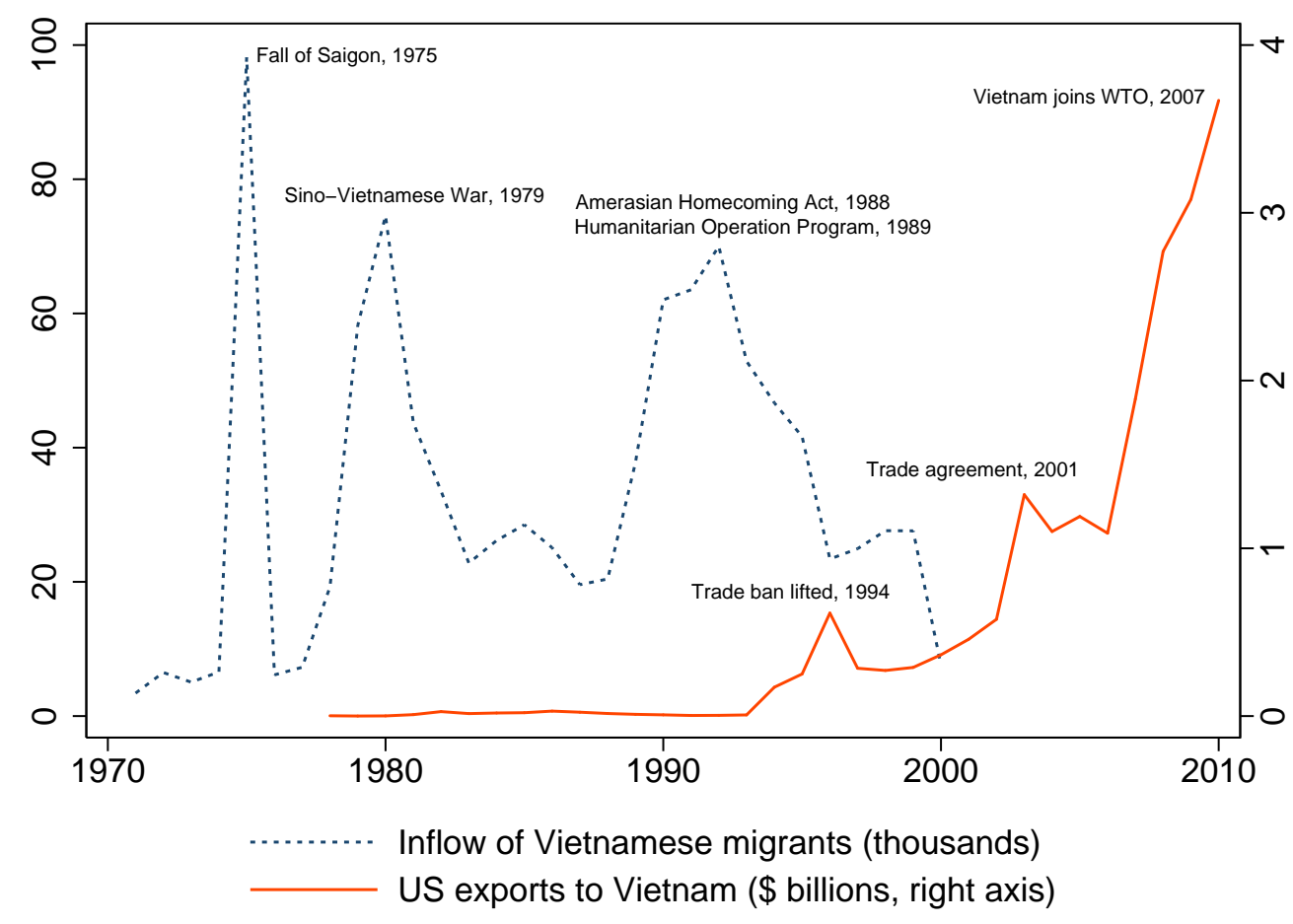

Sources: US Census 2000 and USITC. 
Figure 2: 1995 Vietnamese Migrant Stock vs. 1975 Refugees

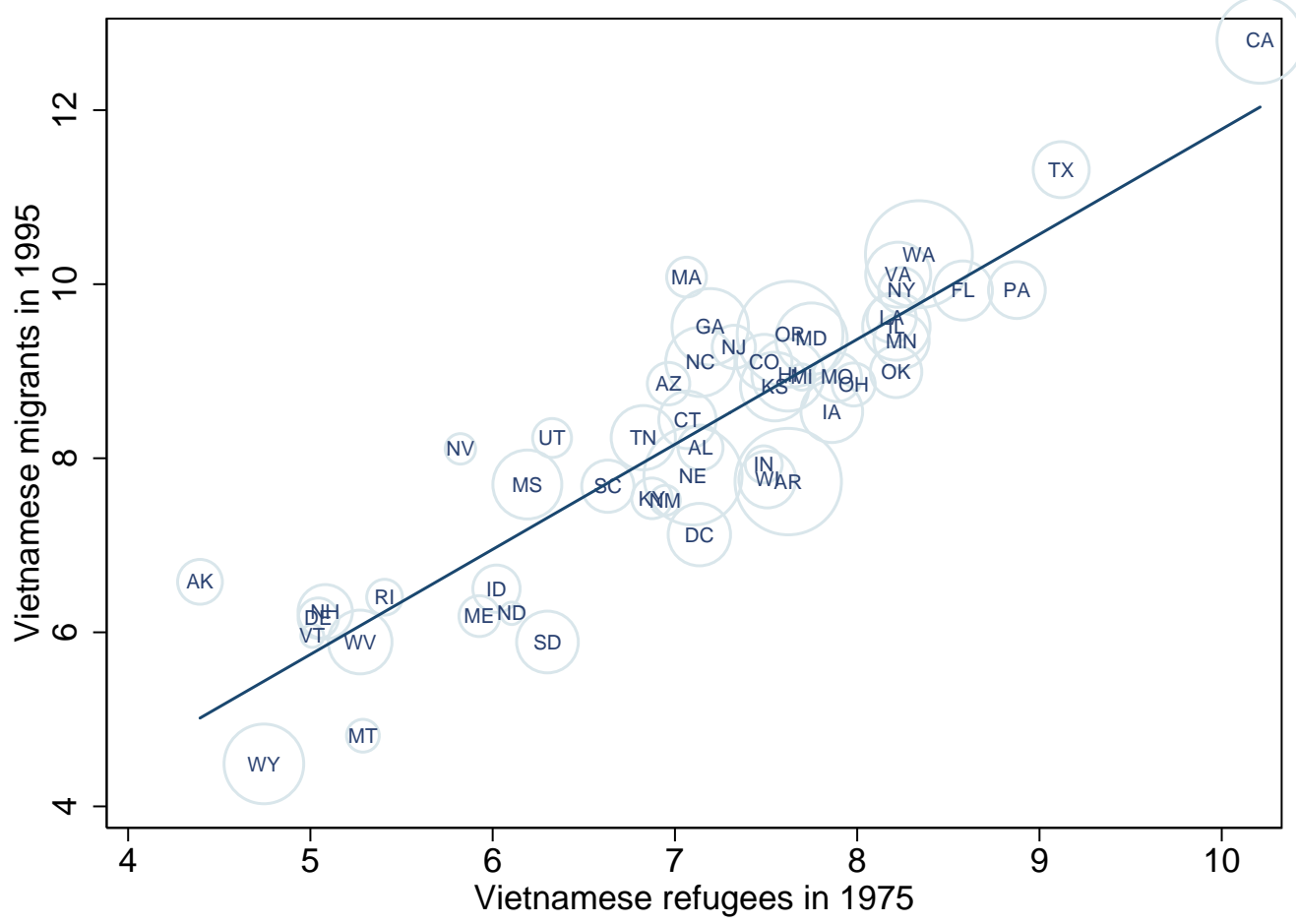

Note: The circles are proportional to the State's average exports to Vietnam as a share of total exports during 1995-2010. Sources: See Section 4

Figure 3: Weekly releases of refugees from camps

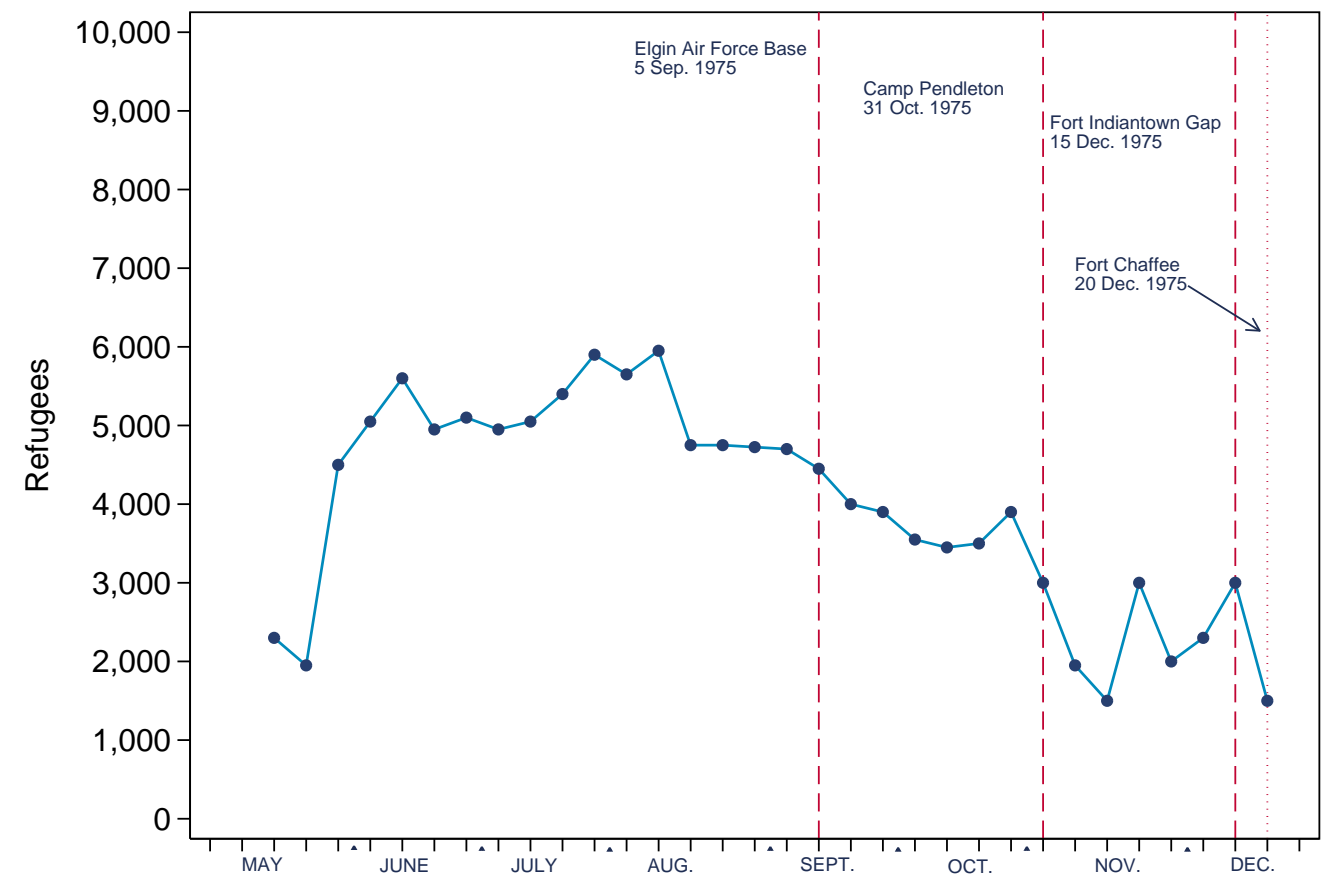

Note: Camp closure dates are in parenthesis. Source: GAO (1976). 

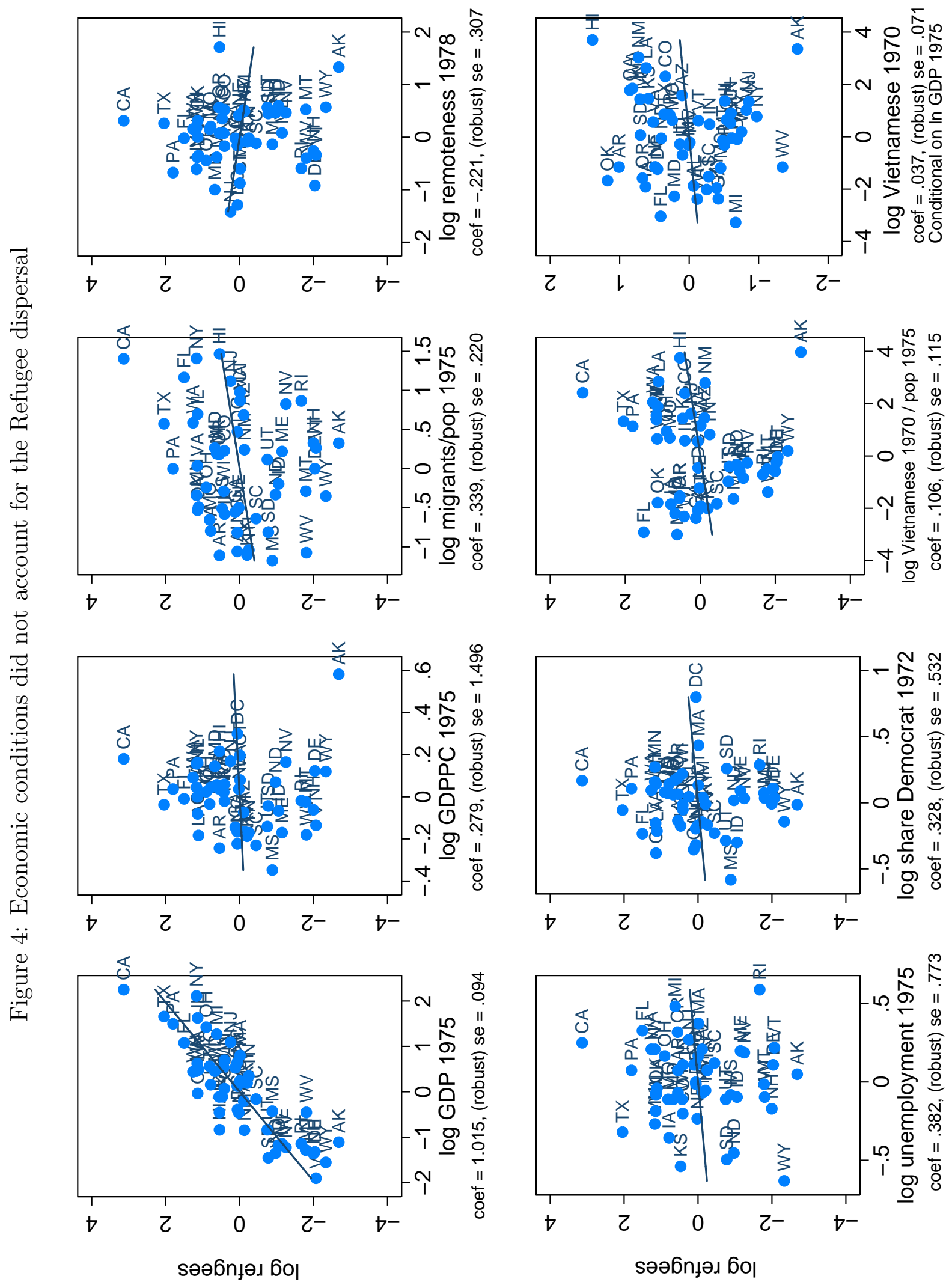

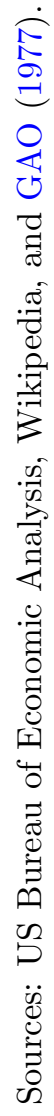



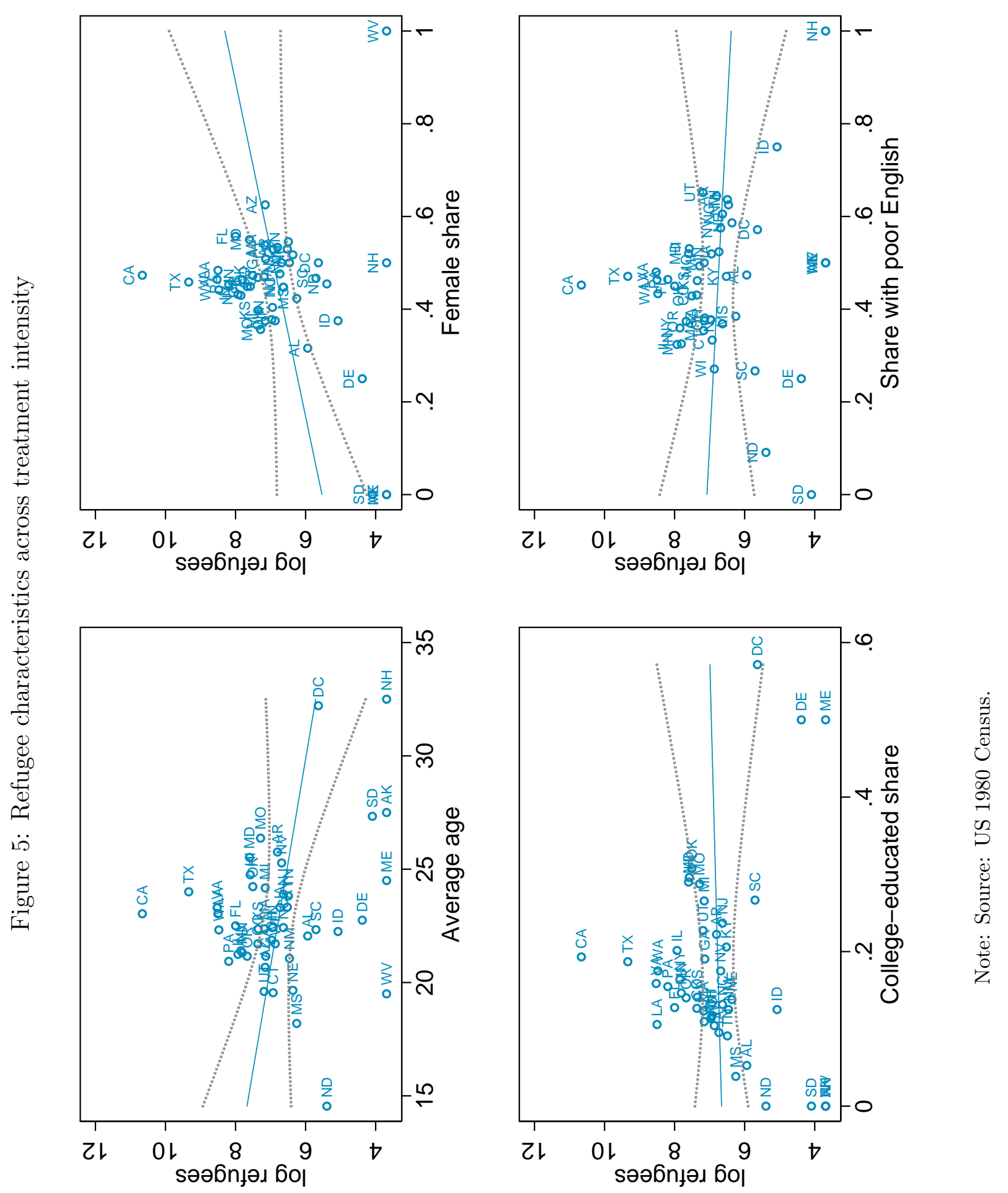


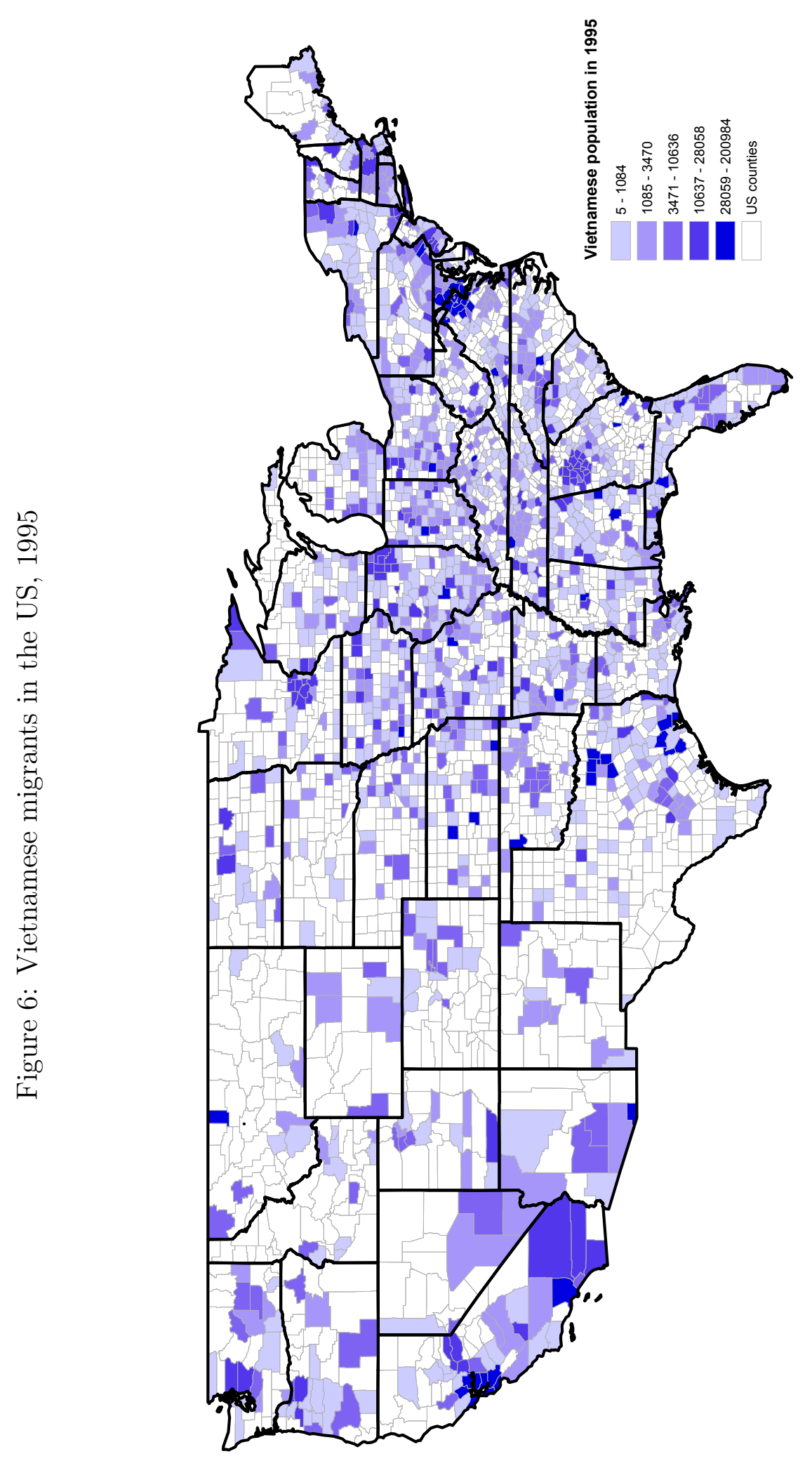

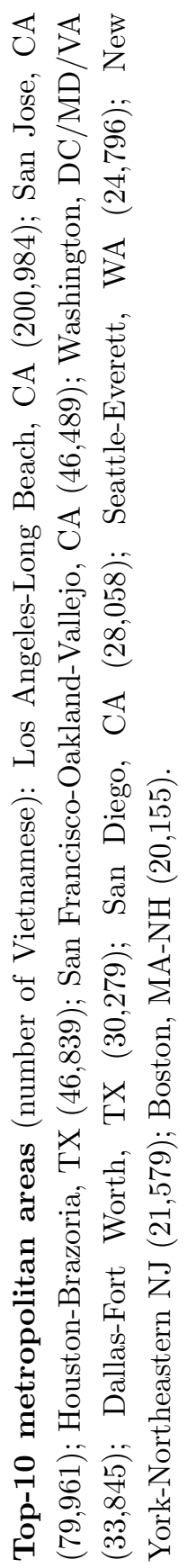


Figure 7: The Pro-Export effect of the Vietnamese
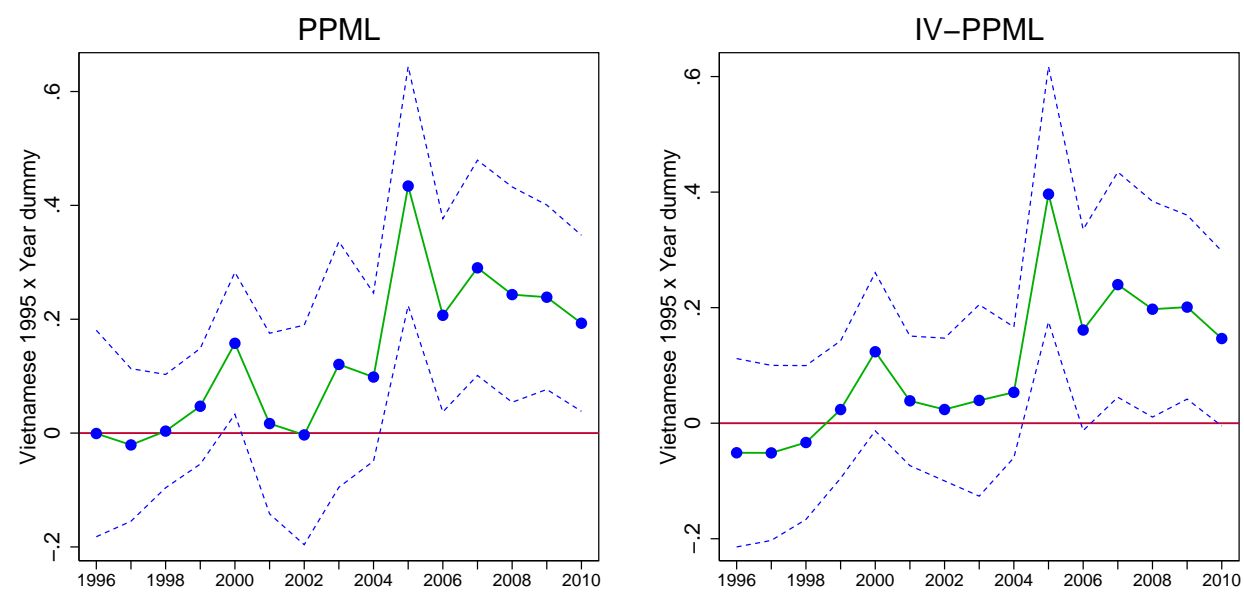

Note: The figures show the effect of 1995 Vietnamese on US exports to Vietnam based on regression results of Table 9 . The dashed lines give the $90 \%$ confidence intervals.

Figure 8: The Pro-Export effect of the Vietnamese
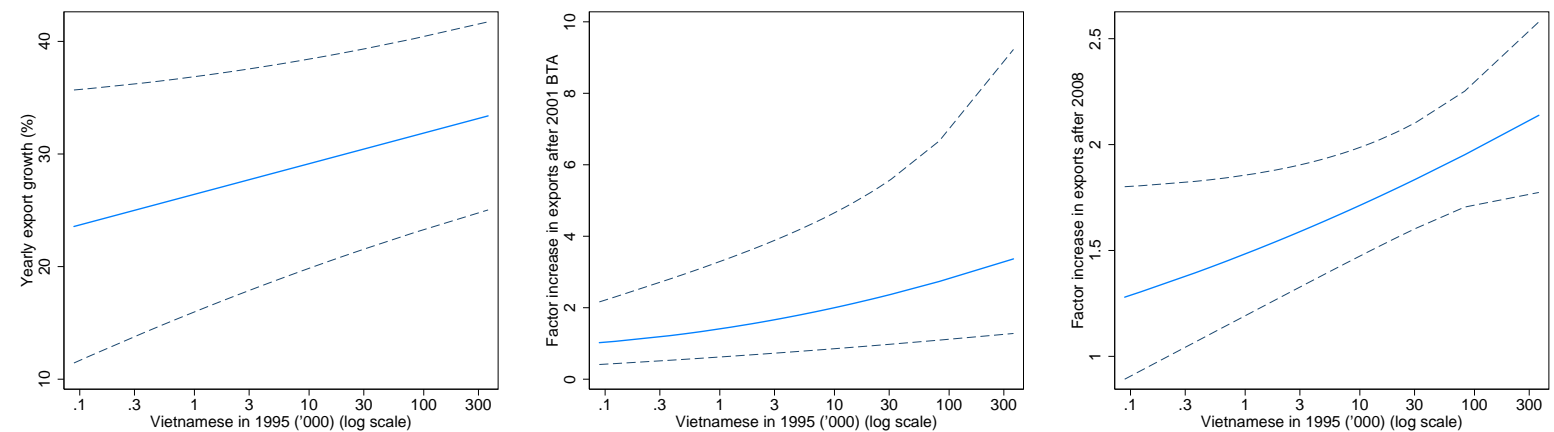

Note: The figures show the effect of 1995 Vietnamese on US exports to Vietnam based on the IV-PPML regression results of Table 10. The dashed lines give the $90 \%$ confidence intervals. 
Figure 9: Case studies
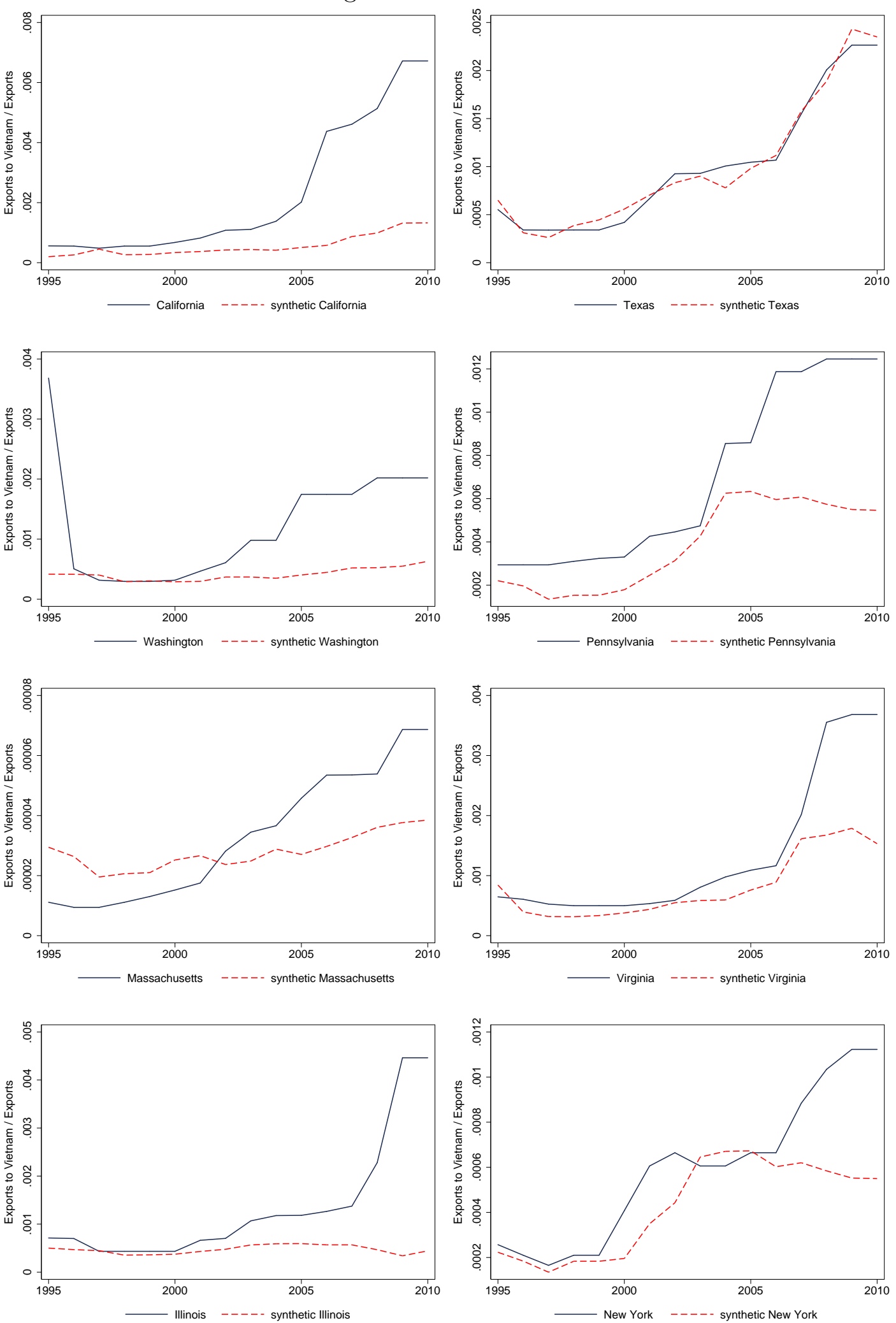

Note: The solid lines plot the data. The dashed lines the synthetic counterfactuals as expalined in Section 4. 
Table 1: The Vietnamese in the United States

\begin{tabular}{|c|c|c|c|c|c|}
\hline State & $\begin{array}{r}\text { Vietnamese } \\
1995\end{array}$ & $\begin{array}{c}\text { \% of pop } \\
1995\end{array}$ & $\begin{array}{r}\text { Refugees } \\
1975\end{array}$ & $\begin{array}{l}\text { Exports } \\
\text { to Vietnam }\end{array}$ & $\begin{array}{c}\% \text { of Exports } \\
1995-2010\end{array}$ \\
\hline California & 364192 & 1.15 & 30495 & 4755.6 & 0.27 \\
\hline Hawaii & 7767 & 0.65 & 2411 & 19.0 & 0.24 \\
\hline Washington & 31103 & 0.57 & 5205 & 2069.7 & 0.34 \\
\hline Texas & 82142 & 0.43 & 11136 & 2327.1 & 0.12 \\
\hline Oregon & 12411 & 0.39 & 2448 & 770.2 & 0.40 \\
\hline Massachusetts & 23890 & 0.39 & 1439 & 182.7 & 0.06 \\
\hline Virginia & 24566 & 0.37 & 5620 & 320.3 & 0.16 \\
\hline Louisiana & 14947 & 0.34 & 3916 & 306.9 & 0.08 \\
\hline Kansas & 6794 & 0.26 & 1953 & 202.8 & 0.20 \\
\hline Minnesota & 11483 & 0.25 & 4250 & 246.2 & 0.12 \\
\hline Oklahoma & 8055 & 0.24 & 3716 & 47.4 & 0.09 \\
\hline Colorado & 8995 & 0.24 & 2350 & 101.9 & 0.10 \\
\hline Maryland & 11773 & 0.23 & 2828 & 186.4 & 0.18 \\
\hline District of Columbia & 1240 & 0.21 & 613 & 15.8 & 0.12 \\
\hline Nevada & 3321 & 0.21 & 519 & 14.4 & 0.03 \\
\hline Utah & 3763 & 0.19 & 964 & 59.0 & 0.06 \\
\hline Georgia & 13501 & 0.18 & 1622 & 666.9 & 0.23 \\
\hline Iowa & 5094 & 0.18 & 3352 & 174.5 & 0.17 \\
\hline Pennsylvania & 20583 & 0.17 & 8187 & 411.9 & 0.12 \\
\hline Arizona & 7027 & 0.16 & 1444 & 148.9 & 0.07 \\
\hline Nebraska & 2433 & 0.15 & 1418 & 205.7 & 0.42 \\
\hline Florida & 20492 & 0.14 & 5237 & 572.4 & 0.11 \\
\hline Missouri & 7575 & 0.14 & 3154 & 122.5 & 0.09 \\
\hline Connecticut & 4634 & 0.14 & 1304 & 218.5 & 0.14 \\
\hline New Jersey & 10717 & 0.13 & 1918 & 235.2 & 0.07 \\
\hline North Carolina & 9022 & 0.12 & 1334 & 525.0 & 0.18 \\
\hline Alaska & 721 & 0.12 & 94 & 26.4 & 0.05 \\
\hline Illinois & 13543 & 0.11 & 4675 & 945.8 & 0.17 \\
\hline New York & 20490 & 0.11 & 4749 & 597.7 & 0.08 \\
\hline New Mexico & 1837 & 0.11 & 1047 & 8.6 & 0.03 \\
\hline Arkansas & 2280 & 0.09 & 2127 & 198.1 & 0.36 \\
\hline Mississippi & 2205 & 0.08 & 493 & 132.9 & 0.21 \\
\hline Alabama & 3368 & 0.08 & 1439 & 123.1 & 0.08 \\
\hline Michigan & 7578 & 0.08 & 2949 & 131.4 & 0.02 \\
\hline North Dakota & 502 & 0.08 & 408 & 3.7 & 0.02 \\
\hline Tennessee & 3777 & 0.07 & 1250 & 421.2 & 0.18 \\
\hline Vermont & 387 & 0.07 & 106 & 9.7 & 0.02 \\
\hline Delaware & 475 & 0.07 & 173 & 33.3 & 0.08 \\
\hline Ohio & 6961 & 0.06 & 3496 & 338.3 & 0.07 \\
\hline Rhode Island & 604 & 0.06 & 545 & 9.1 & 0.04 \\
\hline South Carolina & 2162 & 0.06 & 926 & 202.3 & 0.11 \\
\hline Idaho & 666 & 0.06 & 421 & 48.4 & 0.10 \\
\hline South Dakota & 361 & 0.05 & 604 & 22.9 & 0.18 \\
\hline Kentucky & 1881 & 0.05 & 1174 & 129.1 & 0.07 \\
\hline Indiana & 2780 & 0.05 & 2175 & 149.4 & 0.05 \\
\hline Wisconsin & 2338 & 0.05 & 2461 & 254.2 & 0.12 \\
\hline New Hampshire & 511 & 0.04 & 171 & 42.9 & 0.11 \\
\hline Maine & 486 & 0.04 & 376 & 18.6 & 0.05 \\
\hline West Virginia & 361 & 0.02 & 268 & 57.2 & 0.12 \\
\hline Wyoming & 89 & 0.02 & 143 & 23.1 & 0.22 \\
\hline Montana & 123 & 0.01 & 360 & 4.7 & 0.05 \\
\hline
\end{tabular}

Note: States are ranked by Vietnamese share of pop in 1995. Exports are the sum of US Exports to Vietnam from 1995-2010 in USD million. 
Table 2: Matching NAICS to SIC and the Rauch goods classification

\begin{tabular}{cllcr}
\hline NAICS & NAICS description & SIC & Rauch & Exports \\
\hline 111 & Agricultural Products & 1 & $\mathrm{~W}$ & 1598.6 \\
112 & Livestock \& Livestock Products & 2 & $\mathrm{~W}$ & 13.5 \\
113 & Forestry Products, Nesoi & 8 & $\mathrm{r}$ & 210 \\
114 & Fish, Fresh/chilled/frozen \& Other Marine Products & 9 & $\mathrm{r}$ & 92.4 \\
211 & Oil \& Gas & 13 & $\mathrm{~W}$ & 0.7 \\
212 & Minerals \& Ores & 10 & $\mathrm{w}$ & 38.6 \\
311 & Food \& Kindred Products & 20 & $\mathrm{n}$ & 2614.7 \\
312 & Beverages \& Tobacco Products & 21 & $\mathrm{n}$ & 223.7 \\
313 & Textiles \& Fabrics & & $\mathrm{n}$ & 96.9 \\
314 & Textile Mill Products & 22 & $\mathrm{r}$ & 18.3 \\
315 & Apparel \& Accessories & 23 & $\mathrm{n}$ & 38 \\
316 & Leather \& Allied Products & 31 & $\mathrm{n}$ & 382.5 \\
321 & Wood Products & 24 & $\mathrm{r}$ & 473.7 \\
322 & Paper & 26 & $\mathrm{r}$ & 349.3 \\
323 & Printed Matter \& Related Products, Nesoi & 27 & $\mathrm{n}$ & 25.9 \\
324 & Petroleum \& Coal Products & 29,12 & $\mathrm{~W}$ & 36.2 \\
325 & Chemicals & 28 & $\mathrm{r}$ & 1908.3 \\
326 & Plastics \& Rubber Products & 30 & $\mathrm{n}$ & 153.7 \\
327 & Nonmetallic Mineral Products & 14,32 & $\mathrm{r}$ & 107.6 \\
331 & Primary Metal Mfg & 33 & $\mathrm{r}$ & 372.5 \\
332 & Fabricated Metal Products, Nesoi & 34 & $\mathrm{n}$ & 185.9 \\
333 & Machinery, Except Electrical & 35 & $\mathrm{n}$ & 1701.5 \\
334 & Computer \& Electronic Products & 38 & $\mathrm{n}$ & 1670.8 \\
335 & Electrical Equipment, Appliances \& Components & 36 & $\mathrm{n}$ & 261.8 \\
336 & Transportation Equipment & 37 & $\mathrm{n}$ & 3244.1 \\
337 & Furniture \& Fixtures & 25 & $\mathrm{n}$ & 16.1 \\
339 & Miscellaneous Manufactured Commodities & $39,3 \mathrm{X}$ & $\mathrm{n}$ & 267.7 \\
511 & Newspapers, Books \& Other Published Matter, Nesoi & & $\mathrm{n}$ & 3.3 \\
512 & Published Printed Music \& Music Manuscripts & & $\mathrm{n}$ & 0 \\
910 & Waste \& Scrap & 91 & $\mathrm{n}$ & 789.5 \\
920 & Used Or Second-h\& Merch\&ise & 92 & $\mathrm{n}$ & 36.4 \\
980 & Goods Returned (exports For Canada Only) & & $\mathrm{n}$ & 0 \\
990 & Special Classification Provisions, Nesoi & 99 & $\mathrm{n}$ & 116.7 \\
\hline
\end{tabular}

Note: The Rauch column tags the categories as w=goods traded on an organized exchange (homogeneous goods), $\mathrm{r}=$ reference priced, $\mathrm{n}=$ differentiated products. See Rauch (1999). Exports are the sum of US Exports to Vietnam from 1995-2010 in USD million. 
Table 3: Summary Statistics

\begin{tabular}{|c|c|c|c|c|c|c|}
\hline \multicolumn{7}{|c|}{1995} \\
\hline Variable & Obs & Mean & Std. Dev. & Min & Max & Source \\
\hline Exports to Vietnam $(\$)$ & 51 & 3980812 & 8203810 & 0 & $4.18 \mathrm{E}+07$ & US Census Bureau \\
\hline Homogenous Exports to Vietnam $(\$)$ & 51 & 1523512 & 5260308 & 0 & $3.59 \mathrm{E}+07$ & US Census Bureau \\
\hline Differentiated Exports to Vietnam $(\$)$ & 51 & 2433845 & 5174244 & 0 & $3.24 \mathrm{E}+07$ & US Census Bureau \\
\hline Exports to the World $(\$)$ & 51 & $1.01 \mathrm{E}+10$ & $1.54 \mathrm{E}+10$ & $2.67 \mathrm{E}+08$ & $8.67 \mathrm{E}+10$ & US Census Bureau \\
\hline NAICS exported to Vietnam & 51 & 6.33 & 4.81 & 0 & 24 & US Census Bureau \\
\hline Total NAICS exported & 51 & 20.96 & 7.06 & 0 & 27 & US Census Bureau \\
\hline Vietnamese & 51 & 15568.75 & 51428.50 & 89 & 364192 & IPUMS \\
\hline Chinese & 51 & 15599.06 & 46664.54 & 389 & 270765 & IPUMS \\
\hline Asians & 51 & 136896.90 & 376671.50 & 3329 & 2604856 & IPUMS \\
\hline 1975 refugees & 51 & 2369.22 & 3987.10 & 81 & 27199 & US General Accounting Office \\
\hline Income per capita $(\$)$ & 51 & 22482.00 & 3284.12 & 17176 & 31366 & US Bureau of Economic Analysis \\
\hline GDP (\$ millions $)$ & 51 & 143125.00 & 165893.60 & 13891 & 911577 & US Bureau of Economic Analysis \\
\hline Manufacturing share & 51 & 0.86 & 0.11 & 0.410081 & 0.962703 & US Bureau of Economic Analysis \\
\hline West Coast & 51 & 0.06 & 0.24 & 0 & 1 & Google Maps \\
\hline East Coast & 51 & 0.27 & 0.45 & 0 & 1 & Google Maps \\
\hline \multicolumn{7}{|c|}{$1995-2010$} \\
\hline Variable & Obs & Mean & Std. Dev. & Min & Max & Source \\
\hline Exports to Vietnam $(\$)$ & 816 & $2.31 \mathrm{E}+07$ & $7.61 \mathrm{E}+07$ & 0 & $9.62 \mathrm{E}+08$ & US Census Bureau \\
\hline Exports to the World $(\$)$ & 816 & $1.56 \mathrm{E}+10$ & $2.44 \mathrm{E}+10$ & $2.33 \mathrm{E}+08$ & $2.07 \mathrm{E}+11$ & US Census Bureau \\
\hline NAICS exported to Vietnam & 816 & 12.53 & 7.87 & 0 & 31 & US Census Bureau \\
\hline Total NAICS exported & 816 & 27.43 & 6.01 & 0 & 32 & US Census Bureau \\
\hline Income per capita $(\$)$ & 816 & 31701.22 & 7784.46 & 17176 & 71220 & US Bureau of Economic Analysis \\
\hline GDP $(\$$ millions $)$ & 816 & 216997.80 & 268217.90 & 13891 & 1900463 & US Bureau of Economic Analysis \\
\hline
\end{tabular}

Table 4: First stages

\begin{tabular}{lcc}
\hline \hline & $(1)$ & $(2)$ \\
& $\ln$ (Vietnamese) & $\ln$ (Vietnamese) \\
\hline $\ln$ (Exports to World) & 0.222 & 0.194 \\
& $(0.142)$ & $(0.157)$ \\
$\ln (\mathrm{GDP})$ & $0.421^{*}$ & 0.374 \\
& $(0.227)$ & $(0.285)$ \\
$\ln$ (1975 Refugees) & $0.733^{* * *}$ & $0.741^{* * *}$ \\
& $(0.138)$ & $(0.158)$ \\
$\ln$ (Income per capita) & & 1.057 \\
& & $(0.711)$ \\
$\ln$ (Mfg share of GDP) & & -0.747 \\
& & $(0.480)$ \\
West Coast & & $0.680^{* * *}$ \\
& & $(0.202)$ \\
East Coast & & 0.178 \\
& & $(0.217)$ \\
Constant & $-6.640^{* * *}$ & $-16.318^{* *}$ \\
& $(1.730)$ & $(7.045)$ \\
\hline $\mathrm{N}$ & 51 & 51 \\
R-sq & 0.87 & 0.90 \\
\hline
\end{tabular}

PPML estimates. Dependent variable is Vietnamese in 1995 (logs). The 51 obs. are 50 US States and Washington DC. The figures in parenthesis are robust standard errors, and * stands for statistical significance at the $10 \%$ level, ${ }^{* *}$ at the $5 \%$ level and ${ }^{* * *}$ at the $1 \%$ percent level. 
Table 5: 1995 Cross section

\begin{tabular}{|c|c|c|c|c|c|c|}
\hline & $\begin{array}{c}\text { (1) } \\
\text { Exports to } \\
\text { Vietnam }\end{array}$ & $\begin{array}{c}(2) \\
\text { Exports to } \\
\text { Vietnam }\end{array}$ & $\begin{array}{c}(3) \\
\text { Exports to } \\
\text { Vietnam }\end{array}$ & $\begin{array}{c}(4) \\
\text { Exports to } \\
\text { Vietnam }\end{array}$ & $\begin{array}{c}(5) \\
\text { Exports to } \\
\text { Vietnam }\end{array}$ & $\begin{array}{c}\text { (6) } \\
\text { Exports to } \\
\text { Vietnam }\end{array}$ \\
\hline & PPML & PPML-RF & IV-PPML & PPML & PPML-RF & IV-PPML \\
\hline ln (Exports to World) & $\begin{array}{c}0.208 \\
(0.249)\end{array}$ & $\begin{array}{c}0.328 \\
(0.300)\end{array}$ & $\begin{array}{c}0.156 \\
(0.280)\end{array}$ & $\begin{array}{c}0.271 \\
(0.314)\end{array}$ & $\begin{array}{c}0.842^{* * *} \\
(0.293)\end{array}$ & $\begin{array}{c}0.148 \\
(0.491)\end{array}$ \\
\hline $\ln (\mathrm{GDP})$ & $\begin{array}{c}0.445 \\
(0.536)\end{array}$ & $\begin{array}{c}0.367 \\
(0.488)\end{array}$ & $\begin{array}{c}0.356 \\
(0.470)\end{array}$ & $\begin{array}{c}0.297 \\
(0.660)\end{array}$ & $\begin{array}{l}-0.818 \\
(0.626)\end{array}$ & $\begin{array}{l}-0.724 \\
(0.737)\end{array}$ \\
\hline ln (Vietnamese) & $\begin{array}{c}0.360^{*} \\
(0.188)\end{array}$ & & $\begin{array}{l}0.453^{* *} \\
(0.195)\end{array}$ & $\begin{array}{l}0.483^{* *} \\
(0.239)\end{array}$ & & $\begin{array}{l}1.381^{* *} \\
(0.662)\end{array}$ \\
\hline ln (1975 Refugees) & & $\begin{array}{c}0.459^{* *} \\
(0.206)\end{array}$ & & & $\begin{array}{c}1.073^{* * *} \\
(0.335)\end{array}$ & \\
\hline ln (Income per capita) & & & & $\begin{array}{l}-2.870 \\
(1.859)\end{array}$ & $\begin{array}{l}-1.675 \\
(1.422)\end{array}$ & $\begin{array}{l}-3.115 \\
(2.931)\end{array}$ \\
\hline ln (Mfg share of GDP) & & & & $\begin{array}{c}0.464 \\
(0.674)\end{array}$ & $\begin{array}{l}1.403^{* *} \\
(0.689)\end{array}$ & $\begin{array}{c}1.334 \\
(0.852)\end{array}$ \\
\hline West Coast & & & & $\begin{array}{c}0.268 \\
(0.360)\end{array}$ & $\begin{array}{c}0.082 \\
(0.317)\end{array}$ & $\begin{array}{l}-0.692 \\
(0.652)\end{array}$ \\
\hline East Coast & & & & $\begin{array}{l}1.054^{* *} \\
(0.482)\end{array}$ & $\begin{array}{c}1.493^{* * *} \\
(0.423)\end{array}$ & $\begin{array}{c}1.256 \\
(0.782)\end{array}$ \\
\hline Constant & $\begin{array}{c}1.758 \\
(2.742)\end{array}$ & $\begin{array}{l}-0.307 \\
(2.823)\end{array}$ & $\begin{array}{c}3.144 \\
(3.329)\end{array}$ & $\begin{array}{c}29.334 \\
(18.524)\end{array}$ & $\begin{array}{c}13.672 \\
(14.446)\end{array}$ & $\begin{array}{c}38.527 \\
(33.444)\end{array}$ \\
\hline $\mathrm{N}$ & 51 & 51 & 51 & 51 & 51 & 51 \\
\hline R-sq & 0.64 & 0.65 & & 0.75 & 0.85 & \\
\hline
\end{tabular}


Table 6: 1995 Cross section: Extensive margin

\begin{tabular}{|c|c|c|c|c|c|c|}
\hline & $\begin{array}{c}(1) \\
\text { Ext. margin } \\
\text { PPML }\end{array}$ & $\begin{array}{c}(2) \\
\text { Ext. margin } \\
\text { PPML-RF }\end{array}$ & $\begin{array}{c}\text { (3) } \\
\text { Ext. margin } \\
\text { IV-PPML }\end{array}$ & $\begin{array}{c}(4) \\
\text { Ext. margin } \\
\text { PPML }\end{array}$ & $\begin{array}{c}(5) \\
\text { Ext. margin } \\
\text { PPML-RF }\end{array}$ & $\begin{array}{c}(6) \\
\text { Ext. margin } \\
\text { IV-PPML }\end{array}$ \\
\hline $\ln$ (Exports to World) & $\begin{array}{l}0.187^{* *} \\
(0.075)\end{array}$ & $\begin{array}{c}0.214^{* * *} \\
(0.075)\end{array}$ & $\begin{array}{c}0.163 \\
(0.099)\end{array}$ & $\begin{array}{c}0.201^{* * *} \\
(0.072)\end{array}$ & $\begin{array}{l}0.192^{* *} \\
(0.075)\end{array}$ & $\begin{array}{c}0.147 \\
(0.099)\end{array}$ \\
\hline ln (State industries) & $\begin{array}{c}1.240^{* * *} \\
(0.346)\end{array}$ & $\begin{array}{c}1.419^{* * *} \\
(0.460)\end{array}$ & $\begin{array}{c}1.210^{* * * *} \\
(0.334)\end{array}$ & $\begin{array}{c}1.183^{* * *} \\
(0.294)\end{array}$ & $\begin{array}{c}1.264^{* * *} \\
(0.335)\end{array}$ & $\begin{array}{c}1.129^{* * *} \\
(0.282)\end{array}$ \\
\hline ln (Vietnamese) & $\begin{array}{c}0.150^{* * * *} \\
(0.052)\end{array}$ & & $\begin{array}{l}0.177^{* *} \\
(0.083)\end{array}$ & $\begin{array}{l}0.110^{*} \\
(0.058)\end{array}$ & & $\begin{array}{l}0.177^{*} \\
(0.094)\end{array}$ \\
\hline ln (1975 Refugees) & & $\begin{array}{l}0.159^{* *} \\
(0.071)\end{array}$ & & & $\begin{array}{l}0.153^{* *} \\
(0.073)\end{array}$ & \\
\hline ln (Income per capita) & & & & $\begin{array}{c}0.257 \\
(0.412)\end{array}$ & $\begin{array}{c}0.286 \\
(0.401)\end{array}$ & $\begin{array}{c}0.143 \\
(0.421)\end{array}$ \\
\hline West Coast & & & & $\begin{array}{l}0.230^{* *} \\
(0.111)\end{array}$ & $\begin{array}{c}0.285^{* * *} \\
(0.091)\end{array}$ & $\begin{array}{c}0.161 \\
(0.129)\end{array}$ \\
\hline East Coast & & & & $\begin{array}{c}0.098 \\
(0.099)\end{array}$ & $\begin{array}{c}0.162 \\
(0.102)\end{array}$ & $\begin{array}{c}0.108 \\
(0.097)\end{array}$ \\
\hline Constant & $\begin{array}{c}-8.422^{* * *} \\
(1.648) \\
\end{array}$ & $\begin{array}{c}-9.573^{* * *} \\
(1.661) \\
\end{array}$ & $\begin{array}{c}-7.983^{* * *} \\
(1.979)\end{array}$ & $\begin{array}{c}-10.799^{* * *} \\
(3.809)\end{array}$ & $\begin{array}{c}-11.373^{* * *} \\
(3.782)\end{array}$ & $\begin{array}{c}-8.804^{* *} \\
(4.444)\end{array}$ \\
\hline $\mathrm{N}$ & 51 & 51 & 51 & 51 & 51 & 51 \\
\hline R-sq & 0.88 & 0.87 & & 0.88 & 0.89 & \\
\hline $\begin{array}{l}\text { Dependent variable } \\
\text { State industries are } \\
\text { The } 51 \text { obs. are } 50 \\
\text { (reduced form) and } \\
\text { with extra controls. } \\
\text { significance at the } 1\end{array}$ & $\begin{array}{l}\text { is the numbe } \\
\text { the number } \\
\text { US States a } \\
\text { IV-PPML es } \\
\text { The figures i } \\
\text {. }\end{array}$ & $\begin{array}{l}\text { of industrie } \\
\text { industries } \mathrm{f} \\
\mathrm{d} \text { Washingt } \\
\text { mates, resp } \\
\text { parenthesis }\end{array}$ & $\begin{array}{l}\text { (NAICS) witl } \\
\text { which the S } \\
\text { DC. Colum } \\
\text { tively. Colun } \\
\text { e robust stan }\end{array}$ & $\begin{array}{l}\text { positive exp } \\
\text { ate has posit } \\
\text { is } 1 \text { to } 3 \text { give } \\
\text { ins } 4 \text { to } 6 \text { pro } \\
\text { lard errors, al }\end{array}$ & $\begin{array}{l}\text { orts to Vietna } \\
\text { ve exports to } \\
\text { the PPML, } \\
\text { vide the same } \\
\text { d * stands for }\end{array}$ & $\begin{array}{l}\mathrm{m} \text { in } 1995 . \\
\text { the world. } \\
\text { PPML-RF } \\
\text { estimates } \\
\text { statistical }\end{array}$ \\
\hline
\end{tabular}

Table 7: Robustness

\begin{tabular}{|c|c|c|c|c|c|c|c|c|}
\hline & $\begin{array}{c}(1) \\
\text { Export share }\end{array}$ & $\begin{array}{c}(2) \\
\text { GDP share }\end{array}$ & $\begin{array}{c}\text { Without West Coast } \\
\text { We }\end{array}$ & $\begin{array}{c}(4) \\
\text { Without California }\end{array}$ & $\begin{array}{c}\text { (5) } \\
\text { Exports to Vietnam }\end{array}$ & $\begin{array}{c}(6) \\
\text { Exports to Vietnam }\end{array}$ & $\begin{array}{c}(7) \\
\text { Differentiated }\end{array}$ & $\begin{array}{c}(8) \\
\text { Homogenous }\end{array}$ \\
\hline $\ln$ (Vietnamese) & $\begin{array}{l}0.223^{* *} \\
(0.109)\end{array}$ & $\begin{array}{c}0.332^{* * *} \\
(0.121)\end{array}$ & $\begin{array}{l}0.677^{*} \\
(0.388)\end{array}$ & $\begin{array}{l}0.766^{* *} \\
(0.350)\end{array}$ & & & $\begin{array}{l}0.815^{* *} \\
(0.410)\end{array}$ & $\begin{array}{c}3.238 \\
(4.437)\end{array}$ \\
\hline In (Income per capita) & 0.451 & $\begin{array}{l}-1.152 \\
(1.346)\end{array}$ & $\begin{array}{l}-1.014 \\
(1.377)\end{array}$ & $\begin{array}{l}-0.720 \\
(1.295)\end{array}$ & $\begin{array}{l}-0.496 \\
(1.465)\end{array}$ & $\begin{array}{l}-3.198^{* *} \\
(1.580)\end{array}$ & 0.540 & $\begin{array}{l}-11.811 \\
(17841)\end{array}$ \\
\hline $\ln$ (Mfg share of GDP) & $\begin{array}{l}1.142^{*} \\
(0.692)\end{array}$ & $\begin{array}{l}-0.467 \\
(0.565)\end{array}$ & $\begin{array}{l}0.687 \\
(0.965)\end{array}$ & $\begin{array}{c}0.804 \\
(0.866)\end{array}$ & $\begin{array}{l}-0.452 \\
(0.543)\end{array}$ & $\begin{array}{l}-0.048 \\
(0.550)\end{array}$ & & \\
\hline West Coast & $\begin{array}{l}-0.423 \\
(0.416)\end{array}$ & $\begin{array}{c}0.404 \\
(0.515)\end{array}$ & & & $\begin{array}{l}1.510^{* * * *} \\
(0.366)\end{array}$ & $\begin{array}{l}0.912^{* *} \\
(0.446)\end{array}$ & $\begin{array}{l}-0.736 \\
(0.646)\end{array}$ & $\begin{array}{c}0.618 \\
(1.889)\end{array}$ \\
\hline East Coast & $\begin{array}{l}0.518 \\
(0.328)\end{array}$ & $\begin{array}{l}0.760^{*} \\
(0.421)\end{array}$ & & & $\begin{array}{l}0.930^{* *} \\
(0.401)\end{array}$ & $\begin{array}{l}1.027^{* *} \\
(0.462)\end{array}$ & $\begin{array}{l}0.043 \\
(0.485)\end{array}$ & $\begin{array}{l}5.967 \\
(9.321)\end{array}$ \\
\hline $\ln$ (Exports to World) & & & $\begin{array}{l}-0.089 \\
(0.520)\end{array}$ & $\begin{array}{r}-0.019 \\
(0.474)\end{array}$ & $\begin{array}{c}0.243 \\
(0.318)\end{array}$ & $\begin{array}{c}0.342 \\
(0.296)\end{array}$ & & \\
\hline $\ln (\mathrm{GDP})$ & & & $\begin{array}{c}0.599 \\
(0.892)\end{array}$ & $\begin{array}{l}0.387 \\
(0.638)\end{array}$ & $\begin{array}{l}1.849^{* * * *} \\
(0.550)\end{array}$ & $\begin{array}{l}0.854 \\
(0.605)\end{array}$ & $\begin{array}{l}-0.273 \\
(0.699)\end{array}$ & $\begin{array}{l}-3.260 \\
(5.165)\end{array}$ \\
\hline $\ln$ (Chinese) & & & & & $\begin{array}{c}-0.634^{* * * *} \\
(0.229)\end{array}$ & & & \\
\hline $\ln$ (Asians) & & & & & & $\begin{array}{c}0.013 \\
(0.282)\end{array}$ & & \\
\hline ln (Differentiated Exports to World) & & & & & & & $\begin{array}{c}0.331 \\
(0.284)\end{array}$ & \\
\hline In (Homogenous Exports to World) & & & & & & & & $\begin{array}{c}1.166 \\
(2.846)\end{array}$ \\
\hline Constant & $\begin{array}{l}-14.227 \\
(10.893)\end{array}$ & $\begin{array}{c}11.264 \\
(12.838)\end{array}$ & $\begin{array}{c}14.059 \\
(14.977)\end{array}$ & $\begin{array}{c}11.247 \\
(14.450)\end{array}$ & $\begin{array}{c}-2.507 \\
(15.182)\end{array}$ & $\begin{array}{l}28.489^{*} \\
(15.824)\end{array}$ & $\begin{array}{c}-2.461 \\
(19.044)\end{array}$ & $\begin{array}{c}111.655 \\
(152.774)\end{array}$ \\
\hline $\mathrm{N}$ & 51 & 51 & 48 & 50 & 51 & 51 & 51 & 51 \\
\hline
\end{tabular}

IV-PPML estimates. Dependent variable is Exports to Vietnam as a share of the State's total exports in column 1, Exports to Vietnam as a share of the State's GDP in column 2, Exports to Vietnam in columns 3 to 6, Differentiated Exports to Vietnam in column 7 and Homogenous Exports to Vietnam in column 8. The 51 obs. are 50 US States and Washington DC. The figures in parenthesis are robust standard errors, and $*$ stands for statistical significance at the $10 \%$ level, ** at the $5 \%$ level and $* * *$ at the $1 \%$ percent level. 
Table 8: Placebos

\begin{tabular}{lcccccccccccc}
\hline \hline & $(1)$ & $(2)$ & $(3)$ & $(4)$ & $(5)$ & $(6)$ & $(7)$ & $(8)$ & $(9)$ & $(10)$ \\
& Cambodia & China & Indonesia & Japan & Korea & Laos & Malaysia & Philippines & Taiwan & Thailand \\
\hline ln (Vietnamese) & -0.169 & 0.231 & 0.009 & -0.310 & -0.158 & -2.981 & 0.551 & 0.183 & 0.239 & 0.106 \\
& $(0.384)$ & $(0.316)$ & $(0.319)$ & $(0.273)$ & $(0.170)$ & $(4.276)$ & $(0.393)$ & $(0.214)$ & $(0.211)$ & $(0.285)$ \\
ln (Exports to World) & $0.866^{* *}$ & $1.072^{* * *}$ & $0.869^{* * *}$ & $0.789^{* * *}$ & $0.800^{* * *}$ & 0.656 & $0.893^{* * *}$ & $0.842^{* * *}$ & $1.221^{* * *}$ & $0.419^{* * *}$ \\
& $(0.364)$ & $(0.325)$ & $(0.264)$ & $(0.167)$ & $(0.182)$ & $(1.889)$ & $(0.248)$ & $(0.268)$ & $(0.147)$ & $(0.132)$ \\
ln (Income per capita) & 6.047 & -0.400 & -1.047 & 0.992 & 0.744 & -2.634 & -1.547 & $-1.800^{* *}$ & -0.812 & 0.313 \\
& $(5.123)$ & $(1.292)$ & $(1.016)$ & $(0.871)$ & $(0.659)$ & $(5.827)$ & $(1.821)$ & $(0.906)$ & $(0.810)$ & $(1.287)$ \\
$\ln$ (GDP) & 0.941 & -0.386 & 0.169 & 0.385 & 0.334 & 4.447 & -0.555 & -0.033 & $-0.604^{* * *}$ & 0.478 \\
& $(0.577)$ & $(0.624)$ & $(0.471)$ & $(0.309)$ & $(0.292)$ & $(6.934)$ & $(0.541)$ & $(0.397)$ & $(0.216)$ & $(0.471)$ \\
$\ln$ (Mfg share of GDP) & $-4.481^{* * *}$ & $-1.607^{* * *}$ & $-1.062^{* *}$ & $-1.417^{* *}$ & $-1.361^{* * *}$ & 1.412 & $1.045^{* *}$ & -0.055 & -0.098 & -0.481 \\
& $(0.948)$ & $(0.502)$ & $(0.520)$ & $(0.563)$ & $(0.387)$ & $(8.652)$ & $(0.473)$ & $(0.509)$ & $(0.227)$ & $(0.508)$ \\
West Coast & 0.613 & -0.187 & 0.211 & $1.420^{* * *}$ & $1.333^{* * *}$ & 7.916 & 0.600 & $0.894^{* *}$ & $0.606^{* *}$ & 0.811 \\
& $(1.035)$ & $(0.472)$ & $(0.528)$ & $(0.388)$ & $(0.308)$ & $(11.672)$ & $(0.562)$ & $(0.398)$ & $(0.274)$ & $(0.524)$ \\
East Coast & -1.905 & 0.276 & 0.171 & -0.210 & -0.133 & 2.566 & -0.166 & -0.326 & 0.046 & -0.435 \\
& $(1.276)$ & $(0.399)$ & $(0.271)$ & $(0.202)$ & $(0.193)$ & $(2.210)$ & $(0.388)$ & $(0.220)$ & $(0.196)$ & $(0.306)$ \\
Constant & -78.631 & 0.564 & 5.982 & -9.420 & -9.091 & -8.069 & 15.183 & 15.458 & 4.378 & -1.133 \\
& $(53.265)$ & $(14.611)$ & $(10.148)$ & $(10.124)$ & $(7.053)$ & $(47.465)$ & $(16.304)$ & $(9.579)$ & $(7.658)$ & $(11.543)$ \\
\hline $\mathrm{N}$ & 51 & 51 & 51 & 51 & 51 & 51 & 51 & 51 & 51 & 51 \\
\hline
\end{tabular}

IV-PPML estimates. Dependent variable is Exports to placebo country in 1995. The 51 obs. are 50 US States and Washington DC. The figures in parenthesis are robust standard errors, and * stands for statistical significance at the $10 \%$ level, ** at the $5 \%$ level and $* * *$ at the $1 \%$ percent level. 
Table 9: Panel estimates: Year dummies interactions

\begin{tabular}{|c|c|c|}
\hline & $\begin{array}{c}\text { (1) } \\
\text { Exports to Vietnam }\end{array}$ & $\begin{array}{c}(2) \\
\text { Exports to Vietnam }\end{array}$ \\
\hline $\ln$ (Exports to World) & $\begin{array}{c}0.864^{*} \\
(0.500)\end{array}$ & $\begin{array}{c}0.811 \\
(0.536)\end{array}$ \\
\hline ln (Income per capita) & $\begin{array}{l}-2.523^{*} \\
(1.390)\end{array}$ & $\begin{array}{l}-2.529^{*} \\
(1.343)\end{array}$ \\
\hline $\ln (\mathrm{GDP})$ & $\begin{array}{l}-3.957 \\
(2.446)\end{array}$ & $\begin{array}{l}-3.877 \\
(2.481)\end{array}$ \\
\hline $\ln ($ Vietnamese $) \times 1996$ & $\begin{array}{l}-0.001 \\
(0.110)\end{array}$ & $\begin{array}{l}-0.051 \\
(0.099)\end{array}$ \\
\hline $\ln ($ Vietnamese $) \times 1997$ & $\begin{array}{l}-0.021 \\
(0.082)\end{array}$ & $\begin{array}{l}-0.051 \\
(0.092)\end{array}$ \\
\hline $\ln ($ Vietnamese $) \times 1998$ & $\begin{array}{c}0.003 \\
(0.061)\end{array}$ & $\begin{array}{l}-0.033 \\
(0.081)\end{array}$ \\
\hline $\ln ($ Vietnamese $) \times 1999$ & $\begin{array}{c}0.047 \\
(0.062)\end{array}$ & $\begin{array}{c}0.024 \\
(0.072)\end{array}$ \\
\hline $\ln ($ Vietnamese $) \times 2000$ & $\begin{array}{l}0.158^{* *} \\
(0.076)\end{array}$ & $\begin{array}{c}0.124 \\
(0.083)\end{array}$ \\
\hline $\ln ($ Vietnamese $) \times 2001$ & $\begin{array}{c}0.017 \\
(0.096)\end{array}$ & $\begin{array}{c}0.039 \\
(0.068)\end{array}$ \\
\hline $\ln ($ Vietnamese $) \times 2002$ & $\begin{array}{l}-0.003 \\
(0.117)\end{array}$ & $\begin{array}{c}0.024 \\
(0.075)\end{array}$ \\
\hline $\ln ($ Vietnamese $) \times 2003$ & $\begin{array}{c}0.121 \\
(0.131)\end{array}$ & $\begin{array}{c}0.039 \\
(0.101)\end{array}$ \\
\hline $\ln ($ Vietnamese $) \times 2004$ & $\begin{array}{l}0.098 \\
(0.090)\end{array}$ & $\begin{array}{c}0.053 \\
(0.069)\end{array}$ \\
\hline $\ln ($ Vietnamese $) \times 2005$ & $\begin{array}{c}0.434^{* * *} \\
(0.128)\end{array}$ & $\begin{array}{c}0.396^{* * *} \\
(0.134)\end{array}$ \\
\hline $\ln ($ Vietnamese $) \times 2006$ & $\begin{array}{l}0.207^{* *} \\
(0.103)\end{array}$ & $\begin{array}{c}0.161 \\
(0.106)\end{array}$ \\
\hline $\ln ($ Vietnamese $) \times 2007$ & $\begin{array}{l}0.290^{* *} \\
(0.115)\end{array}$ & $\begin{array}{l}0.240^{* *} \\
(0.118)\end{array}$ \\
\hline $\ln ($ Vietnamese $) \times 2008$ & $\begin{array}{l}0.243^{* *} \\
(0.115)\end{array}$ & $\begin{array}{l}0.197^{*} \\
(0.114)\end{array}$ \\
\hline $\ln ($ Vietnamese $) \times 2009$ & $\begin{array}{l}0.239^{* *} \\
(0.098)\end{array}$ & $\begin{array}{l}0.201^{* *} \\
(0.097)\end{array}$ \\
\hline $\ln ($ Vietnamese $) \times 2010$ & $\begin{array}{l}0.193^{* *} \\
(0.094)\end{array}$ & $\begin{array}{c}0.147 \\
(0.092)\end{array}$ \\
\hline 1996 & $\begin{array}{l}1.366 \\
(1.244)\end{array}$ & $\begin{array}{l}1.885 \\
(1.312)\end{array}$ \\
\hline 1997 & $\begin{array}{c}0.985 \\
(0.961)\end{array}$ & $\begin{array}{c}1.300 \\
(1.018)\end{array}$ \\
\hline 1998 & $\begin{array}{l}1.093 \\
(0.750)\end{array}$ & $\begin{array}{c}1.469 \\
(0.949)\end{array}$ \\
\hline 1999 & $\begin{array}{c}1.122 \\
(0.748)\end{array}$ & $\begin{array}{l}1.356 \\
(0.928)\end{array}$ \\
\hline 2000 & $\begin{array}{c}0.567 \\
(0.777)\end{array}$ & $\begin{array}{c}0.910 \\
(0.915)\end{array}$ \\
\hline 2001 & $\begin{array}{l}2.555^{*} \\
(1.308)\end{array}$ & $\begin{array}{l}2.326^{* *} \\
(1.054)\end{array}$ \\
\hline 2002 & $\begin{array}{l}3.178^{* *} \\
(1.573)\end{array}$ & $\begin{array}{l}2.900^{* *} \\
(1.180)\end{array}$ \\
\hline 2003 & $\begin{array}{l}2.980^{*} \\
(1.607)\end{array}$ & $\begin{array}{l}3.795^{* *} \\
(1.635)\end{array}$ \\
\hline 2004 & $\begin{array}{c}3.328^{* * *} \\
(1.218)\end{array}$ & $\begin{array}{c}3.772^{* * *} \\
(1.306)\end{array}$ \\
\hline 2005 & $\begin{array}{c}0.139 \\
(1.035)\end{array}$ & $\begin{array}{c}0.504 \\
(1.137)\end{array}$ \\
\hline 2006 & $\begin{array}{l}2.783^{* *} \\
(1.165)\end{array}$ & $\begin{array}{c}3.239^{* * *} \\
(1.247)\end{array}$ \\
\hline 2007 & $\begin{array}{l}2.693^{* *} \\
(1.263)\end{array}$ & $\begin{array}{l}3.201^{* *} \\
(1.364)\end{array}$ \\
\hline 2008 & $\begin{array}{l}3.648^{* *} \\
(1.437)\end{array}$ & $\begin{array}{l}4.112^{* * *} \\
(1.492)\end{array}$ \\
\hline 2009 & $\begin{array}{c}3.694^{* * *} \\
(1.322)\end{array}$ & $\begin{array}{c}4.065^{* * *} \\
(1.413)\end{array}$ \\
\hline 2010 & $\begin{array}{c}4.425^{* * *} \\
(1.555)\end{array}$ & $\begin{array}{c}4.893^{* * *} \\
(1.641)\end{array}$ \\
\hline $\mathrm{N}$ & 816 & 816 \\
\hline R-sq & 0.85 & \\
\hline State FE & YES & YES \\
\hline
\end{tabular}

PPML (odd columns) and IV-PPML (even columns) estimates. Dependent variable is Exports to Vietnam. The 816 obs. are 50 US States and Washington DC over 16 years (1995-2010). The figures in parenthesis are State-clustered standard errors, and * stands for statistical significance at the $10 \%$ level, ** at the $5 \%$ level and *** at the $1 \%$ percent level. 
Table 10: Panel estimates: Trend, BTA, and Policy interactions

\begin{tabular}{|c|c|c|c|c|c|c|}
\hline & $\begin{array}{c}\text { (1) } \\
\text { Exports to Vietnam }\end{array}$ & $\begin{array}{c}(2) \\
\text { Exports to Vietnam }\end{array}$ & $\begin{array}{c}\text { (3) } \\
\text { Exports to Vietnam }\end{array}$ & $\begin{array}{c}\text { (4) } \\
\text { Exports to Vietnam }\end{array}$ & $\begin{array}{c}\text { (5) } \\
\text { Exports to Vietnam }\end{array}$ & $\begin{array}{c}\text { Exports to Vietnam } \\
\text { Ex }\end{array}$ \\
\hline $\ln$ (Exports to World) & $\begin{array}{l}1.489^{* * *} \\
(0.409)\end{array}$ & $\begin{array}{l}1.467^{* * *} \\
(0.395)\end{array}$ & $\begin{array}{l}-0.089 \\
(0.579)\end{array}$ & $\begin{array}{l}-0.086 \\
(0.578)\end{array}$ & $\begin{array}{c}0.441 \\
(0.289)\end{array}$ & $\begin{array}{c}0.420 \\
(0.283)\end{array}$ \\
\hline ln (Income per capita) & $\begin{array}{l}-0.060 \\
(1.013)\end{array}$ & $\begin{array}{l}-0.068 \\
(0.995)\end{array}$ & $\begin{array}{c}6.569^{* * *} \\
(2.126)\end{array}$ & $\begin{array}{l}6.551^{* * *} \\
(2.114)\end{array}$ & $\begin{array}{c}0.850 \\
(1.079)\end{array}$ & $\begin{array}{c}0.821 \\
(1.090)\end{array}$ \\
\hline $\ln (\mathrm{GDP})$ & $\begin{array}{c}0.764 \\
(2.251)\end{array}$ & $\begin{array}{c}0.807 \\
(2.203)\end{array}$ & $\begin{array}{c}1.528 \\
(1.408)\end{array}$ & $\begin{array}{c}1.524 \\
(1.393)\end{array}$ & $\begin{array}{c}-3.499^{* *} \\
(1.741)\end{array}$ & $\begin{array}{c}-3.449^{* *} \\
(1.753)\end{array}$ \\
\hline ln (Vietnamese $) \times$ BTA & $\begin{array}{c}0.160^{* * *} \\
(0.052)\end{array}$ & $\begin{array}{c}0.149^{* * *} \\
(0.057)\end{array}$ & & & & \\
\hline BTA & $\begin{array}{l}-0.785 \\
(0.562)\end{array}$ & $\begin{array}{l}-0.677 \\
(0.651)\end{array}$ & & & & \\
\hline $\ln ($ Vietnamese $) \times$ Post-2008 & & & $\begin{array}{l}0.063^{* *} \\
(0.031)\end{array}$ & $\begin{array}{c}0.062^{*} \\
(0.032)\end{array}$ & & \\
\hline Post-2008 & & & $\begin{array}{l}-0.047 \\
(0.339)\end{array}$ & $\begin{array}{l}-0.034 \\
(0.339)\end{array}$ & & \\
\hline $\ln ($ Vietnamese $) \times$ Trend & & & & & $\begin{array}{l}0.013^{* *} \\
(0.005)\end{array}$ & $\begin{array}{l}0.012^{*} \\
(0.006)\end{array}$ \\
\hline Trend & & & & & $\begin{array}{l}0.171^{*} \\
(0.092)\end{array}$ & $\begin{array}{l}0.183^{*} \\
(0.095)\end{array}$ \\
\hline $\mathrm{N}$ & 816 & 816 & 255 & 255 & 816 & 816 \\
\hline R-sq & 0.73 & & 0.97 & & 0.80 & \\
\hline State FE & YES & YES & YES & YES & YES & YES \\
\hline $\begin{array}{l}\text { PPML (1) and IV-F } \\
\text { States and Washingt } \\
\text { parenthesis are State }\end{array}$ & $\begin{array}{l}\text { PML (2) estim } \\
\text { on DC over } 16 y\end{array}$ & $\begin{array}{l}\text { ates. Depende } \\
\text { jears (1995-2010 } \\
\text { lard errors, and }\end{array}$ & $\begin{array}{l}\text { it variable is Ex } \\
\text { ). The } 255 \text { obs. }\end{array}$ & $\begin{array}{l}\text { ports to Vietna } \\
\text { cover only the y }\end{array}$ & $\begin{array}{l}\text { m. The } 816 \text { ol } \\
\text { ears } 2006-2010 \text {. } \\
\text { ice at the } 10 \% \text { l }\end{array}$ & $\begin{array}{l}\text { s. are } 50 \mathrm{US} \\
\text { The figures in } \\
\text { evel, ** at the }\end{array}$ \\
\hline
\end{tabular}


Editor, UWA Economics Discussion Papers:

Sam Hak Kan Tang

University of Western Australia

35 Sterling Hwy

Crawley WA 6009

Australia

Email: ecoadmin@biz.uwa.edu.au

The Economics Discussion Papers are available at:

1980 - 2002: http://ecompapers.biz.uwa.edu.au/paper/PDF\%20of\%20Discussion\%20Papers/

Since 2001: http://ideas.repec.org/s/uwa/wpaper1.html

Since 2004: http://www.business.uwa.edu.au/school/disciplines/economics

\begin{tabular}{|c|c|c|}
\hline \multicolumn{3}{|c|}{$\begin{array}{l}\text { ECONOMICS DISCUSSION PAPERS } \\
2015\end{array}$} \\
\hline $\begin{array}{l}\text { DP } \\
\text { NUMBER }\end{array}$ & AUTHORS & TITLE \\
\hline 15.01 & Robertson, P.E. and Robitaille, M.C. & $\begin{array}{l}\text { THE GRAVITY OF RESOURCES AND THE TYRANNY OF } \\
\text { DISTANCE }\end{array}$ \\
\hline 15.02 & Tyers, R. & $\begin{array}{l}\text { FINANCIAL INTEGRATION AND CHINA'S GLOBAL } \\
\text { IMPACT }\end{array}$ \\
\hline 15.03 & Clements, K.W. and Si, J. & $\begin{array}{l}\text { MORE ON THE PRICE-RESPONSIVENESS OF FOOD } \\
\text { CONSUMPTION }\end{array}$ \\
\hline 15.04 & Tang, S.H.K. & $\begin{array}{l}\text { PARENTS, MIGRANT DOMESTIC WORKERS, AND } \\
\text { CHILDREN'S SPEAKING OF A SECOND LANGUAGE: } \\
\text { EVIDENCE FROM HONG KONG }\end{array}$ \\
\hline 15.05 & Tyers, R. & $\begin{array}{l}\text { CHINA AND GLOBAL MACROECONOMIC } \\
\text { INTERDEPENDENCE }\end{array}$ \\
\hline 15.06 & $\begin{array}{l}\text { Fan, J., Wu, Y., Guo, X., Zhao, D. and } \\
\text { Marinova, D. }\end{array}$ & $\begin{array}{l}\text { REGIONAL DISPARITY OF EMBEDDED CARBON } \\
\text { FOOTPRINT AND ITS SOURCES IN CHINA: A } \\
\text { CONSUMPTION PERSPECTIVE }\end{array}$ \\
\hline 15.07 & $\begin{array}{l}\text { Fan, J., Wang, S., Wu, Y., Li, J. and } \\
\text { Zhao, D. }\end{array}$ & $\begin{array}{l}\text { BUFFER EFFECT AND PRICE EFFECT OF A PERSONAL } \\
\text { CARBON TRADING SCHEME }\end{array}$ \\
\hline 15.08 & Neill, K. & $\begin{array}{l}\text { WESTERN AUSTRALIA'S DOMESTIC GAS } \\
\text { RESERVATION POLICY THE ELEMENTAL ECONOMICS }\end{array}$ \\
\hline 15.09 & Collins, J., Baer, B. and Weber, E.J. & THE EVOLUTIONARY FOUNDATIONS OF ECONOMICS \\
\hline 15.10 & $\begin{array}{l}\text { Siddique, A., Selvanathan, E. A. and } \\
\text { Selvanathan, S. }\end{array}$ & $\begin{array}{l}\text { THE IMPACT OF EXTERNAL DEBT ON ECONOMIC } \\
\text { GROWTH: EMPIRICAL EVIDENCE FROM HIGHLY } \\
\text { INDEBTED POOR COUNTRIES }\end{array}$ \\
\hline 15.11 & Wu, Y. & $\begin{array}{l}\text { LOCAL GOVERNMENT DEBT AND ECONOMIC } \\
\text { GROWTH IN CHINA }\end{array}$ \\
\hline 15.12 & Tyers, R. and Bain, I. & $\begin{array}{l}\text { THE GLOBAL ECONOMIC IMPLICATIONS OF FREER } \\
\text { SKILLED MIGRATION }\end{array}$ \\
\hline 15.13 & Chen, A. and Groenewold, N. & $\begin{array}{l}\text { AN INCREASE IN THE RETIREMENT AGE IN CHINA: } \\
\text { THE REGIONAL ECONOMIC EFFECTS }\end{array}$ \\
\hline 15.14 & Knight, K. & PIGOU, A LOYAL MARSHALLIAN? \\
\hline
\end{tabular}




\begin{tabular}{|c|c|c|}
\hline 15.15 & Kristoffersen, I. & $\begin{array}{l}\text { THE AGE-HAPPINESS PUZZLE: THE ROLE OF } \\
\text { ECONOMIC CIRCUMSTANCES AND FINANCIAL } \\
\text { SATISFACTION }\end{array}$ \\
\hline 15.16 & Azwar, P. and Tyers, R. & INDONESIAN MACRO POLICY THROUGH TWO CRISES \\
\hline 15.17 & Asano, A. and Tyers, R. & $\begin{array}{l}\text { THIRD ARROW REFORMS AND JAPAN'S ECONOMIC } \\
\text { PERFORMANCE }\end{array}$ \\
\hline 15.18 & Arthmar, R. and McLure, M. & $\begin{array}{l}\text { ON BRITAIN'S RETURN TO THE GOLD STANDARD: } \\
\text { WAS THERE A 'PIGOU-MCKENNA SCHOOL'? }\end{array}$ \\
\hline 15.19 & $\begin{array}{l}\text { Fan, J., Li, Y., Wu, Y., Wang, S., and } \\
\text { Zhao, D. }\end{array}$ & $\begin{array}{l}\text { ALLOWANCE TRADING AND ENERGY CONSUMPTION } \\
\text { UNDER A PERSONAL CARBON TRADING SCHEME: A } \\
\text { DYNAMIC PROGRAMMING APPROACH }\end{array}$ \\
\hline 15.20 & Shehabi, M. & $\begin{array}{l}\text { AN EXTRAORDINARY RECOVERY: KUWAIT } \\
\text { FOLLOWING THE GULF WAR }\end{array}$ \\
\hline 15.21 & $\begin{array}{l}\text { Siddique, A., Sen, R., and Srivastava, } \\
\text { S. }\end{array}$ & $\begin{array}{l}\text { AUSTRALIA-THAILAND TRADE: AN ANALYSIS OF } \\
\text { COMPETITIVENESS AND THE EFFECTS OF THE } \\
\text { BILATERAL FTA }\end{array}$ \\
\hline 15.22 & Tyers, R. & $\begin{array}{l}\text { SLOWER GROWTH AND VULNERABILITY TO } \\
\text { RECESSION: UPDATING CHINA'S GLOBAL IMPACT }\end{array}$ \\
\hline 15.23 & Arthmar, R. and McLure, M. & PIGOU ON WAR FINANCE AND STATE ACTION \\
\hline 15.24 & Wu, Y. & $\begin{array}{l}\text { CHINA'S CAPITAL STOCK SERIES BY REGION AND } \\
\text { SECTOR }\end{array}$ \\
\hline 15.25 & Clements, K. and Si, J. & $\begin{array}{l}\text { ENGEL'S LAW, DIET DIVERSITY AND THE QUALITY } \\
\text { OF FOOD CONSUMPTION }\end{array}$ \\
\hline 15.26 & Chen, S. & $\begin{array}{l}\text { SHIFTS OF DISTORTION AND CORRUPTION OVER } \\
\text { LOCAL POLITICAL CYCLES IN CHINA }\end{array}$ \\
\hline 15.27 & Chen, S. & $\begin{array}{l}\text { THE EFFECT OF A FISCAL SQUEEZE ON TAX } \\
\text { NFORCEMENT: EVIDENCE FROM A NATURAL } \\
\text { EXPERIMENT IN CHINA }\end{array}$ \\
\hline 15.28 & Jetter, M. & $\begin{array}{l}\text { BLOWING THINGS UP: THE EFFECT OF MEDIA } \\
\text { ATTENTION ON TERRORISM }\end{array}$ \\
\hline 15.29 & Tang, S. & $\begin{array}{l}\text { MEDIUM-TERM MACROECONOMIC VOLATILITY AND } \\
\text { ECONOMIC DEVELOPMENT: A NEW TECHNIQUE }\end{array}$ \\
\hline 15.30 & Alim, A., Hartley, P. and Lan, Y. & $\begin{array}{l}\text { ASIAN SPOT PRICES FOR LNG OTHER ENERGY } \\
\text { COMMODITIES }\end{array}$ \\
\hline 15.31 & $\begin{array}{l}\text { Gannon, B., Harris, D., Harris, M., } \\
\text { Magnusson, L., Hollingsworth, B., } \\
\text { Inder, B., Maitra, P, and Munford, L. }\end{array}$ & $\begin{array}{l}\text { NEW APPROACHES TO ESTIMATING THE CHILD } \\
\text { HEALTH-PARENTAL INCOME RELATIONSHIP }\end{array}$ \\
\hline 15.32 & Czaika, M. and Parsons, C. & $\begin{array}{l}\text { THE GRAVITY OF HIGH SKILLED MIGRATION } \\
\text { POLICIES }\end{array}$ \\
\hline 15.33 & $\begin{array}{l}\text { Parsons, C., Rojon, S., Samanani, F, } \\
\text { and Wettach, L. }\end{array}$ & $\begin{array}{l}\text { CONCEPTUALISING INTERNATIONAL HIGH-SKILLED } \\
\text { MIGRATION }\end{array}$ \\
\hline 15.34 & Chen, S. & $\begin{array}{l}\text { VAT RATE DISPERSION AND TFP LOSS IN CHINA'S } \\
\text { MANUFACTURING SECTOR }\end{array}$ \\
\hline 15.35 & Tait, L., Siddique, A. and Chatterjee, I. & $\begin{array}{l}\text { FOREIGN AID AND ECONOMIC GROWTH IN SUB- } \\
\text { SAHARAN AFRICA }\end{array}$ \\
\hline
\end{tabular}




\begin{tabular}{|c|c|c|}
\hline \multicolumn{3}{|c|}{$\begin{array}{l}\text { ECONOMICS DISCUSSION PAPERS } \\
2016\end{array}$} \\
\hline $\begin{array}{l}\text { DP } \\
\text { NUMBER }\end{array}$ & AUTHORS & TITLE \\
\hline 16.01 & Xu, R., Wu, Y. and Luan, J. & $\begin{array}{l}\text { ANALYSIS OF FARMERS' WILLINGNESS TO ADOPT } \\
\text { GENETICALLY MODIFIED INSECT-RESISTANT RICE IN } \\
\text { CHINA }\end{array}$ \\
\hline 16.02 & $\begin{array}{l}\text { Lia, Y., Fan, J., Zhao, D., Wu, Y. } \\
\text { and Li, J. }\end{array}$ & $\begin{array}{l}\text { TIERED GASOLINE PRICING: A PERSONAL CARBON } \\
\text { TRADING PERSPECTIVE }\end{array}$ \\
\hline 16.03 & Clements, K.W., Lan, Y. and Si, J. & UNCERTAINTY IN CURRENCY MISPRICING \\
\hline 16.04 & Parsons, C. and Vézina, P.L. & $\begin{array}{l}\text { MIGRANT NETWORKS AND TRADE:THE VIETNAMESE } \\
\text { BOAT PEOPLE AS A NATURAL EXPERIMENT }\end{array}$ \\
\hline 16.05 & Chang, S., Connelly, R. and Ma, P. & $\begin{array}{l}\text { WHAT WILL YOU DO IF I SAY ‘I DO’?: THE EFFECT OF } \\
\text { THE SEX RATIO ON TIME USE WITHIN TAIWANESE } \\
\text { MARRIED COUPLES }\end{array}$ \\
\hline 16.06 & $\mathrm{Yu}, \mathrm{F}$. and $\mathrm{Wu}, \mathrm{Y}$. & $\begin{array}{l}\text { BIASES IN PATENT EXAMINATION AND FIRMS’ } \\
\text { RESPONSES: EVIDENCE FROM THE } \\
\text { PHARMACEUTICAL INDUSTRY }\end{array}$ \\
\hline 16.07 & $\begin{array}{l}\text { Fan, J., Li, J., Wu, Y., Wang, S. and } \\
\text { Zhao, D. }\end{array}$ & $\begin{array}{l}\text { THE EFFECTS OF ALLOWANCE PRICE ON ENERGY } \\
\text { DEMAND UNDER A PERSONAL CARBON TRADING } \\
\text { SCHEME }\end{array}$ \\
\hline 16.08 & Golley, J., Tyers, R. and Zhou, Y. & $\begin{array}{l}\text { CONTRACTIONS IN CHINESE FERTILITY AND } \\
\text { SAVINGS: LONG RUN DOMESTIC AND GLOBAL } \\
\text { IMPLICATIONS }\end{array}$ \\
\hline 16.09 & McGrath, G. and Neill, K. & $\begin{array}{l}\text { FOREIGN AND DOMESTIC OWNERSHIP IN WESTERN } \\
\text { AUSTRALIA'S GAS MARKET }\end{array}$ \\
\hline 16.10 & Clements, K.W. and Si, J. & SIMPLIFYING THE BIG MAC INDEX \\
\hline 16.11 & Priyati, R.Y. and Tyers, R. & $\begin{array}{l}\text { PRICE RELATIONSHIPS IN VEGETABLE OIL AND } \\
\text { ENERGY MARKETS }\end{array}$ \\
\hline 16.12 & Wu, J., Wu, Y. and Wang, B. & $\begin{array}{l}\text { THE GREENNESS OF CHINESE CITIES: CARBON } \\
\text { DIOXIDE EMISSION AND ITS DETERMINANTS }\end{array}$ \\
\hline 16.13 & $\begin{array}{l}\text { Arslan, C., Dumont, J.C., Kone, Z., } \\
\text { Özden, Ç., Parsons, C. and } \\
\text { Xenogiani, T. }\end{array}$ & $\begin{array}{l}\text { INTERNATIONAL MIGRATION TO THE OECD IN THE } \\
\text { TWENTY-FIRST CENTURY }\end{array}$ \\
\hline 16.14 & Tomioka, K. and Tyers, R. & $\begin{array}{l}\text { HAS FOREIGN GROWTH CONTRIBUTED TO } \\
\text { STAGNATION AND INEQUALITY IN JAPAN? }\end{array}$ \\
\hline 16.15 & Donovan, J. and Hartley, P. & $\begin{array}{l}\text { RIDING THE IRON ORE CYCLE: ACTIONS OF } \\
\text { AUSTRALIA'S MAJOR PRODUCERS }\end{array}$ \\
\hline
\end{tabular}

